\title{
HOTAIR: An Oncogenic Long Non-Coding RNA in Human Cancer
}

\author{
Qing Tang ${ }^{a, b}$ Swei Sunny Hannn \\ aLaboratory of Tumor Biology, Guangdong Provincial Hospital of Chinese Medicine, Guangzhou, \\ Guangdong Province, ${ }^{b}$ Guangdong Provincial Key Laboratory of Clinical Research on Traditional \\ Chinese Medicine Syndrome, Guangdong Provincial Hospital of Chinese Medicine, Guangzhou \\ University of Chinese Medicine, Guangzhou, Guangdong Province, China
}

\section{Key Words}

Long non-coding RNAs • HOTAIR • Cancers • Biomarkers $•$ Therapeutic targets

\begin{abstract}
Long non-coding RNAs (LncRNAs) represent a novel class of noncoding RNAs that are longer than 200 nucleotides without protein-coding potential and function as novel master regulators in various human diseases, including cancer. Accumulating evidence shows that IncRNAs are dysregulated and implicated in various aspects of cellular homeostasis, such as proliferation, apoptosis, mobility, invasion, metastasis, chromatin remodeling, gene transcription, and posttranscriptional processing. However, the mechanisms by which IncRNAs regulate various biological functions in human diseases have yet to be determined. HOX antisense intergenic RNA (HOTAIR) is a recently discovered IncRNA and plays a critical role in various areas of cancer, such as proliferation, survival, migration, drug resistance, and genomic stability. In this review, we briefly introduce the concept, identification, and biological functions of HOTAIR. We then describe the involvement of HOTAIR that has been associated with tumorigenesis, growth, invasion, cancer stem cell differentiation, metastasis, and drug resistance in cancer. We also discuss emerging insights into the role of HOTAIR as potential biomarkers and therapeutic targets for novel treatment paradigms in cancer.
\end{abstract}

(C) 2018 The Author(s)

Published by S. Karger AG, Basel

\section{Introduction}

HOTAIR, a polyadenylated RNA with 2158 nucleotides and 6 exons, is transcribed from the antisense strand of the HOXC gene cluster, which is specifically located between HoxC11 and HoxC12 on chromosome 12q13.13 (Fig. 1) [1]. HOTAIR has been shown to function as a key regulator of chromatin states and dynamics by binding to the specific chromatin modification complex polycomb repressive complex 2 (PRC2), thereby recruiting and affecting PRC2 occupancy on genes genome-wide [2, 3]. Knockdown of HOTAIR activates the gene transcriptional activity of the HOXD locus on chromosome 2 by decreasing H3K27 trimethylation, which is the characteristic of gene silencing regulated by the histone methyltransferase enhancer of zeste homolog 2 (EZH2), a member of the PRC2 class (Fig. 
2)[4]. However, no influence is exerted on the transcription of the HOXC gene cluster, where HOTAIR is coded. These observations suggest that HOTAIR regulates gene expression in the transregulatory fashion [5]. In addition, the effect of HOTAIR on EZH2 can be competed binding by BRCA1, a critical player in DNA damage response and genomic integrity [6]. HOTAIR is also shown to interact with the lysine-specific histone demethylase 1A (LSD1). The latter is a flavin-dependent monoamine oxidase, which regulates the methylation of lysine 4 of histone $\mathrm{H} 3$ (H3K4) and plays a central role in epigenetic regulation.

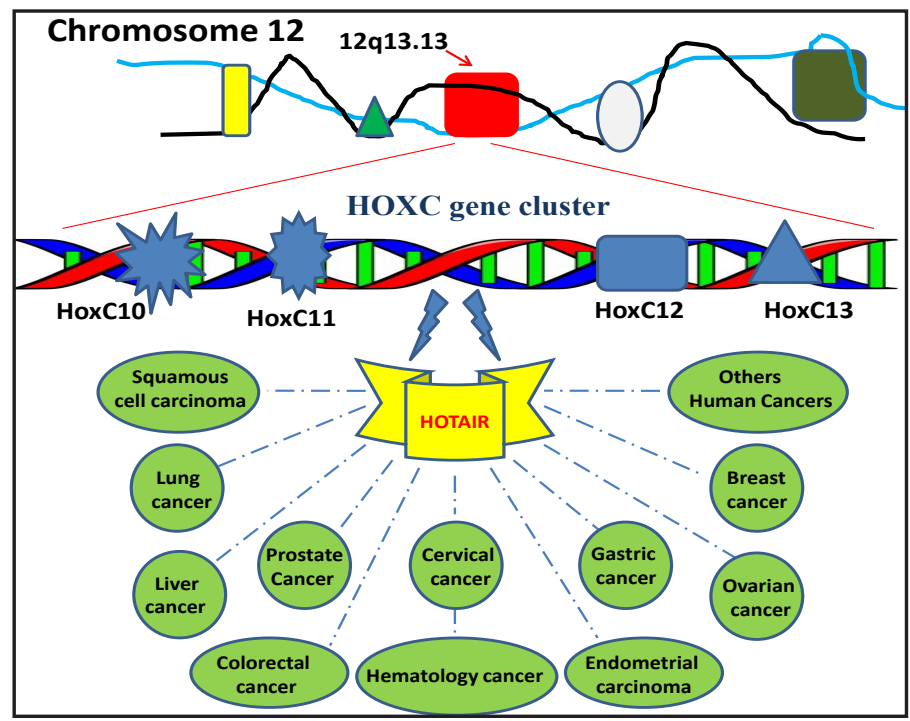

Fig. 1. Structure and genomic location of IncRNA HOTAIR, and association with a variety of human cancers. HOTAIR gene is located HoxC gene cluster from 12q13.13 on chromosome 12, specifically between HoxC11 and HoxC12. The expression of HOTAIR is association with occurrence and development of human cancers.

Moreover, LSD1 can form a multiprotein complex via activation of the RE1-silencing transcription factor (REST) and CoREST, which are critical players in gene silencing (Fig. 2) [7]. Histone methylation is a complex and dynamic method of epigenetic modification involved in the regulation of gene transcription, chromosomal structure, and cell proliferation/differentiation. HOTAIR functions together with chromatinmodifying enzymes to promote the epigenetic activation or silencing of gene expression. Interestingly, PRC2 and LSD1 are disparate for the binding domains with HOTAIR: PRC2 binds to the 5'-end of HOTAIR (1-300 nt), and LSD1 binds to the 3'-end of HOTAIR (1500 to $2146 \mathrm{nt}$ ) (Fig. 2). The interaction between LSD1 and EZH2 modifies histone methylation at a certain gene locus and recruits to respective gene promoters, leading to epigenetic changes and transcriptional regulation [8]. Thus, PRC2 and LSD1 contribute to the targeted gene silencing and repress their transcription via H3K27 trimethylation (PRC2 activity) and H3K4 demethylation (LSD1 activity) (Fig. 2) [7-9]. In addition, HOTAIR affects miRNAmediated suppression of target gene expression by competitive binding to miRNAs (Fig. 2). Notably, HOTAIR occupancy is reportedly preserved upon EZH2 depletion, R57 which implies that HOTAIR binds to its targeted chromatin regions independent of PRC2 [2, 10]. HOTAIR can also alter gene expression at the post-transcriptional level by base pairing with translation factors or ribosomes to control translation or by binding to splicing factors to modulate splicing. Aberrantly increased HOTAIR expression has been detected in several tumors, and HOTAIR expression has been positively correlated with initiation, growth, angiogenesis, progression, drug resistance, recurrence, and poor prognosis by regulating several downstream targets via multiple signaling pathways in cancer [11-15] (Table 1). Polymorphisms of IncRNAs, including HOTAIR polymophisms, have been associated with the risk and susceptibility of the occurrence and development of human cancer; whether this is a potentially predictive and therapeutic biomarker remains undetermined [16-20]. Thus, lncRNAs, including HOTAIR, drive important cancer phenotypes by their interactions with other cellular macromolecules, including DNA, protein, and RNA. This finding renders these molecules attractive as targets for therapeutic intervention in cancer. 


\section{Cellular Physiology Cell Physiol Biochem 2018;47:893-913 \begin{tabular}{ll|l} 
and Biochemistry Published online: May 29, 2018 & $\begin{array}{l}\text { (c) } 2018 \text { The Author(s). Published by S. Karger AG, Basel } \\
\text { www.karger.com/cpb }\end{array}$
\end{tabular}

\section{HOTAIR in solid malignancies}

\section{HOTAIR in lung cancer}

Lung cancer is the first leading cause of cancer-related deaths worldwide. Studies have shown that HOTAIR is highly expressed in non-small cell lung cancer (NSCLC) relative to that in normal lung tissues, and is involved in cell migration, growth, invasion, and metastasis [21-25]. Aberrant HOTAIR expression is correlated with metastasis and poor prognosis; in addition, it is considered a potential biomarker for patients with NSCLC. One study found that HOTAIR was significantly upregulated in NSCLC tissues and regulated invasion and metastasis by reducing homeodomain protein A5 or HOXA5, a tumor suppressor gene, in NSCLC cells [26]. Another study found that HOTAIR was negatively correlated with the FOXA1-to-FOXA2 ratio, members of the forkhead box containing the transcription factor family [27]. HOTAIR also interacted with the chromatin remodeling factor LSH, which prompted LSH binding to the promoter of FOXA1; this occurrence suggests that HOTAIR mediated in the regulation of the FOXA1-to-FOXA2 ratio, resulting in migration and invasion in lung adenocarcinoma cancer (LAD) [28]. In addition, plasma HOTAIR levels were shown to be higher in patients with NSCLC than in healthy controls and were associated with histology subtypes and tumor-node-metastasis stages; this finding suggests that HOTAIR exhibits potential as a biomarker for diagnosing and monitoring patients with NSCLC [29]. One study observed that cigarette smoke extract (CSE) stimulated HOTAIR expression and that cytokine interleukin-6 increased HOTAIR expression via a signal transducer and activator of transcription 3 (Stat3) signaling, which contributed to epithelial-mesenchymal transition (EMT) and formation of cancer stem cells (CSCs) induced by CSE. These findings suggest an association between inflammation and EMT mediated through HOTAIR, which was involved in lung carcinogenesis caused by CSE [30]. Currently, the mechanisms underlying the resistance to chemotherapeutic agents remain poorly understood. Accumulating evidence suggests that HOTAIR plays an important role in mediating drug resistance. For example, HOTAIR expression was significantly increased in cisplatin-resistant A549/DDP cells compared relative to that in parental A549 cells, Moreover, knockdown of HOTAIR can sensitize the responses of A549/DDP cells to cisplatin by regulating $\mathrm{p} 21^{\mathrm{WAF} 1 / \mathrm{CIP} 1} \quad(\mathrm{p} 21)$ expression both in vitro and in vivo [31]. Another study showed that HOTAIR expression was higher in tissues of drugresistant patients with NSCLC than those of non-drug-resistant patients. HOTAIR expression was elevated in cisplatin-resistant cell strains (A549/CDDP), and reduction of HOTAIR increased the sensitivity of A549/ CDDP cells to cisplatin [32].

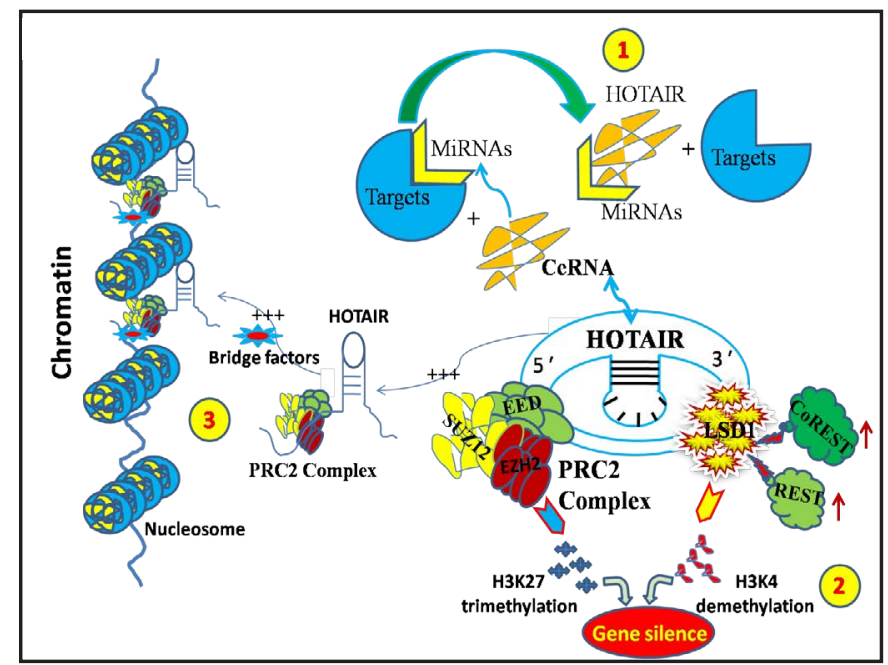

Fig. 2. Functions and mechanisms of HOTAIR-mediated gene silencing, regulation of chromatin dynamics, and association between HOTAIR and miRNAs in human cancers. 1) HOTAIR regulates the levels of genes through interaction with miRNAs as a competitive endogenous RNA (ceRNA). 2) The 5'-domain of HOTAIR binds to polycomb repressive complex 2 (PRC2, including SUZ12, EED and EZH2). The 3 '-domain of HOTAIR binds to the LSD1/CoREST/REST complex. H3K27 trimethylation and H3K4 demethylation were introduced by respectively PRC2 Complex2 and LSD1/CoREST/REST complex, which co-contribute to gene silencing. 3) With the bridge factors, HOTAIR can achieve the regulation of chromatin region and gene expression by guiding the histone modifiers, such as PRC2. 
Moreover, HOTAIR repression reversed chemoresistance in LAD cells partially by regulating the miR-326/ SP1 pathways [33]. MiR326 is regulated by HOTAIR and Phox2a, a vertebrate homeodomain transcription factor. In general, miR-326 regulates cell proliferation and migration by targeting Phox2a, which is regulated by HOTAIR in lung cancer cells [34]. Disruption of the p53 pathway is one of the major mechanisms underlying tumor formation and progression in various types of cancers, including lung cancer. A study found that HOTAIR was negatively correlated with p53 functionality rather than expression in lung cancer; in addition, p53 protein could bind to the promoter region of HOTAIR and suppressed HOTAIR transcription. By contrast, HOTAIR inhibited p53 expression by enhancing H3K27 trimethylation (H3K27me3), a hallmark of gene silencing. This effect suggests a reciprocal regulation axis of lncRNA HOTAIR and p53, which reduces proliferation and invasion capacity in lung cancer cells [22]. A xenograft model of Lewis lung carcinoma in C57BL/6 mice was established to investigate the possible involvement of HOTAIR in radiotherapy. Overexpressed HOTAIR was found to reduce radiosensitivity, and radiotherapy was shown to induce apoptosis of Lewis lung carcinoma cells via inhibition of HOTAIR-mediated inactivation of $\beta$-catenin signaling [35]. Overall, the aforementioned findings indicate the involvement of HOTAIR in the control of apoptosis, growth, metastasis, DNA repair, tumor cell metabolism, development, and progression. With its dynamic role considered, HOTAIR may also serve as a novel biomarker and a therapeutic target, prevent the development of resistance, and inhibit metastatic spread, among others, in human lung cancer via multiple molecular mechanisms.

\section{HOTAIR in hepatocellular carcinoma}

Liver cancer, the fifth leading cause of cancer-related deaths, has resulted in high mortality rates with poor prognosis worldwide. Accumulated evidence has shown the involvement of HOTAIR in tumorigenesis and its dysregulation in hepatocellular carcinoma (HCC). Studies on the potential functions and roles of HOTAIR in HCC have also been conducted. A study determined HOTAIR expression in 60 paired HCC samples and adjacent normal liver tissues. Consistent with other studies [36], the results indicated that HOTAIR expression was higher in HCC tissues than in adjacent non-cancerous tissues and significantly associated with poor differentiation, metastasis, progression, and recurrence [36-38]. Suppression of HOTAIR promoted the inhibition of cell proliferation and invasion by reducing of the 


\section{Cellular Physiology Cell Physiol Biochem 2018;47:893-913 \\ \begin{tabular}{l|l|l} 
and BiOChemistry & Dublished online: May 29, 2018 & $\begin{array}{l}\text { C } 2018 \text { The Author(s). Published by S. Karger AG, Basel } \\
\text { www.karger.com/cpb }\end{array}$
\end{tabular} \\ Tang/Hann: HOTAIR in Human Cancer}

Wnt and $\beta$-catenin signaling pathways, sensitized tumor necrosis factor alpha-induced apoptosis, and increased chemotherapeutic sensitivity to cisplatin and doxorubicin in HCC cells. Thus, targeting HOTAIR can potentially become a novel therapeutic strategy and provide a prognostic biomarker for HCC [36, 37]. Cancer stem cells exhibit the capacity to self-renew, which may be the source of all tumor cells presented in a malignant tumor and provide capability to distant metastases, hence the resistance to chemotherapeutic agents. One study found that HOTAIR regulated the functions of IKK $\alpha / \mathrm{IKK} \beta / \mathrm{IKK} \gamma$ axis in HCC stem cells, implying that the cooperation of IKK $\alpha$, IKK $\beta$, and IKK $\gamma$ with HOTAR could be used as a potential novel therapeutic target for HCC treatment [39]. Another study indicated that HOTAIR promoted the growth of human HCC stem cell by reducing the SET domaincontaining 2 (SETD2), a histone modifier for which mutations have been associated with the occurrence and progression of cancer [40]. Moreover, HOTAIR reduced the recruitment of transcription factors cAMP response binding protein, p300, and RNA polymerase II onto the SETD2 promoter region that inhibited activation and expression of SETD2. The current study proves the critical role of HOTAIR in promoting tumorigenesis in liver cancer stem cells [40]. HOTAIR also negatively regulated miR-218 expression in HCC via an EZH2-targeting miR-218 promoter regulatory axis. Silencing of HOTAIR inhibited cell viability and induced G1-phase arrest by stimulating miR-218 expression. Inhibition of HOTAIR also activated expressions of P16 (INK4a) and P14 (ARF), the main downstream targets of miR-218 and 2 tumor suppressor genes, by enhancing miR-218 and suppressing B lymphoma Mo-MLV insertion region 1 homolog (Bmi-1), a member of the polycomb-group gene family [41], resulting in the inhibition of tumorigenesis in HCC [42]. In addition, HOTAIR increased the migration and invasion of HCC cells by inhibiting the expression of RNA-binding motif protein 38 [43]. Knockdown of HOTAIR inhibited cell proliferation and induced G0/G1 cell cycle arrest in Huh7 HCC cells by reducing the expression levels of Stat3 and cyclin D1 [44]. Transcription factor FOXC1 binds to the upstream region of HOTAIR and stimulates HOTAIR expression in HCC cells, suggesting that HOTAIR is a FOXC1-activated driver of HCC progression [45]. The effect of HOTAIR overexpression on glucose metabolism was also examined by detecting lactate and glucose levels. HOTAIR promoted glycolysis by upregulating glucose transporter isoform 1 (GLUT1) and activating mammalian target of rapamycin (mTOR) signaling. The present study evaluated the relationship between HOTAIR and glucose metabolism in HCC cells [46]. In a recent study, HOTAIR stimulated HCC cell proliferation by regulating the opioid growth factor receptor, a negative biological regulator of cell proliferation [12]. Liver fibrosis is an active wound healing process that leads to portal hypertension and liver cirrhosis, resulting in HCC. Activation of hepatic stellate cells (HSCs) is the key process in liver fibrogenesis. HOTAIR was shown to significantly increase in human fibrotic livers and HSCs. HOTAIR overexpression promoted HSC proliferation. Mechanistically, HOTAIR as an endogenous "sponge" of miR-148b was found to regulate the expression of the DNMT1/maternally expressed gene 3 (MEG3)/p53 pathways in HSCs by enhancing PRC2 occupancy and histone H3K27me3 in the MEG3 promoter. This suggests that inhibition of HOTAIR may represent a potential therapeutic for liver fibrosis [47]. Overall, overexpression of HOTAIR is strongly associated with unfavorable prognosis for patients with HCC. HOTAIR promotes the carcinogenic activity of HCC cells via multiple mechanisms, such as the suppression of RNA-binding motif protein, triggering of EMT, and interaction with miRNAs, among others. This suggests that HOTAIR is a promising therapeutic target for HCC [48]. The role of HOTAIR in chemoresistance has also been examined. Knockdown of HOTAIR resulted in decreased cell proliferation and increased chemosensitivity to cisplatin in HCC cells by inactivating Stat 3 and inhibiting the expression of ATP-binding cassette subfamily B member 1 [49]. In a study evaluating whether common single nucleotide polymorphisms (SNPs) in HOTAIR are related to HCC susceptibility, significant association was observed between HOTAIR rs920778 C>T polymorphism and risk of HCC occurrence; in addition, the rs 920778 TT genotype induced significantly higher expression levels of HOTAIR, compared with the CC genotype. These findings suggest that the HOTAIR SNP rs920778 could be used to predict HCC development, although further studies were required to confirm the findings [50]. 


\section{Cellular Physiology Cell Physiol Biochem 2018;47:893-913 \\ \begin{tabular}{l|l} 
and Biochemistry Published online: May 29, 2018 & $\begin{array}{l}\text { (c) 2018 The Author(s). Published by S. Karger AG, Basel } \\
\text { www.karger.com/cpb }\end{array}$ \\
\hline
\end{tabular} \\ Tang/Hann: HOTAIR in Human Cancer}

Regardless, further research is greatly desired to elucidate the role and precise molecular mechanisms of HOTAIR in HCC occurrence, development, and progression, as well as the potential use of HOTAIR as a biomarker and effective therapeutic target for HCC.

\section{HOTAIR in prostate cancer}

Prostate cancer (PCa), the most common malignancy in men and comprises $13 \%$ of cancer-related deaths [51]. LncRNAs can promote castration resistance, cell proliferation, invasion, and metastasis in PCa [52]. LncRNAs are newly deciphered "codes" and "special emphasis" in PCa, and an understanding of the role of lncRNAs, while only in its infancy, should present ample opportunities for the discovery of new biomarkers and therapeutic targets in PCa [53]. HOTAIR acts as an androgen-repressed lncRNA. Early studies indicated that androgen receptor (AR) was not only important for the growth and differentiation of a healthy prostate but also played a crucial role in the pathogenesis of PCa. HOTAIR induced AR activation in an androgen-independent manner and played an important role for growth and invasion in PCa cells. HOTAIR also suppressed AR signaling by regulating the PRC2 complex, consequently increasing the stem/progenitor cell population and invasion in PCa cells. Thus, modulation of the PRC2 complex with HOTAIR at the AR promoter region would affect PCa resistance to androgen deprivation therapy [54]. Moreover, HOTAIR was shown to enhance the AR-mediated transcriptional program and drive castration-resistant prostate cancer (CRPC) [55]. Microarray analysis for expression profiling indicated that HOTAIR was highly regulated by genistein, a soy-derived isoflavanoid compound acting as a chemotherapeutic agent against several cancer types [56]. In the link to miRNA, silencing of HOTAIR decreased proliferation, migration, invasion, and induced apoptosis; miR-34a directly targeted HOTAIR in PCa cells, which showed that genistein inhibited the growth of PCa cells by downregulating oncogenic HOTAIR that was also targeted by the tumor suppressor miR-34a [57]. In addition, miR-193a acted as a tumor suppressor, inhibiting growth, migration and invasion in CRPC cells via the regulatory feedback loop of HOTAIR/ EZH2/miR-193a. Thus targeting this aberrantly activated loop could provide a potential therapeutic strategy in PCs [58]. Polyphyllin I (PPI), one of the steroidal saponins in Paris polyphylla, reportedly exhibited antitumor activities. We recently observed that PPI inhibited the growth of CRPC cells by inhibiting HOTAIR expression, thereby repressing EZH2 and DNMT1. This result revealed a novel mechanism for HOTAIR-mediated regulation of DNMT1 and EZH2 in response to PPI in inhibiting the growth of CRPC cells [59]. Interestingly, one study demonstrated the association of HOTAIR polymorphisms and genetic variants with PCa. In the study, 3 HOTAIR polymorphisms (rs12826786, rs1899663, and rs4759314) were associated with the risk of PCa [20]. Whether this risk referred to a risk locus for the occurrence and development of PCa remained inconclusive. Together, the aforementioned observations suggested that HOTAIR could potentially be a novel biomarker for the diagnosis and prognosis of PCa. An understanding of the role of lncRNAs, including HOTAIR, in the pathogenesis of PCa may unveil better opportunities for the discovery of new biomarkers, therapeutic targets, and potential implication of PCa in the clinical setting.

\section{HOTAIR in breast cancer}

Breast cancer is the second leading cause of cancer death among women worldwide. LncRNAs play critical roles in cell proliferation, migration, invasion, and radiotherapy in breast cancer and may provide potential therapeutic targets for breast cancer [60]. A clinical study indicated that high HOTAIR expression in primary breast tumors was significantly associated with poor prognosis, particularly in patients with estrogen receptor (ER)-positive tumors; this finding suggests that HOTAIR could be used as an independent biomarker for predicting the risk of metastasis in ER-positive breast cancer patients [61]. Similarly, an early study showed that HOTAIR was highly expressed in primary and metastatic breast cancer tissues and that the HOTAIR level in primary tumors was an independent risk factor for metastasis and survival. In cell-based experiments, HOTAIR promoted breast cancer cell invasion by recruiting PRC2 to specific targets genes, leading to H3K27 trimethylation and 


\section{Cellular Physiology Cell Physiol Biochem 2018;47:893-913 \\ and Biochemistry Published online: May 29, $2018 \quad \begin{aligned} & \text { DOI: 10.1159/000490131 } \\ & \begin{array}{l}\text { (c) } 2018 \text { The Author(s). Published by S. Karger AG, Basel } \\ \text { www.karger.com/cpb }\end{array}\end{aligned}$ \\ Tang/Hann: HOTAIR in Human Cancer}

epigenetic silencing of suppressor genes [3]. Another study showed that upregulation of HOTAIR enhanced the resistance of breast cancer cells to radiotherapy by downregulating the expression of homeobox D10 (HOXD10), an mRNA encoding a transcriptional repressor that inhibits the expression of cell migration and invasion-associated genes [62]. Thus, HOTAIR can be regarded as a valid therapeutic target for the reversal of radiotherapy resistance in patients with breast cancer [63]. Moreover, knockdown of HOTAIR significantly decreased proliferation, migration, invasion in breast cancer cells by inducing the expression of p53, which might be the direct target of HOTAIR [64]. HOTAIR was also shown to contribute to the maintenance of CSCs. HOTAIR was found to regulate the proliferation, self-renewal capacity, tumor formation, and migration of breast cancer CSCs. It inhibited miR-34a, thereby upregulating the transcription factor Sox2, a target of miR-34a expressed in embryonic and adult stem cells [65]. Furthermore, tight transcriptional regulations of p53 and p21 by HOTAIR were observed in breast cancer cells [66]. An emerging mechanism underlying the upregulation of HOTAIR in cancer cells is the direct transcriptional activation of HOTAIR by classical oncogenes. For instance, both myocardin-related transcription factor-A, a Rho signaling-responsive co-activator of serum response factor (SRF) governed by the Rho GTPase actin signaling pathway, and SRF could affect HOTAIR expression by regulating HOTAIR gene promoter activity in a CArG box (CC(A/T)6GG sequences)-dependent manner in breast cancer cells [67]. FOXA1 and FOXM1, the 2 members of the forkhead box (FOX) transcription factor family and known to be highly expressed in several cancer types, activated HOTAIR expression in breast cancer [68]; the latter was negatively regulated by estrogen [69]. EMT contributes to tumor invasion and metastasis in many types of cancer and highly correlates with the acquisition of CSC characteristics. One study found that treatment with transforming growth factor beta 1 (TGF- $\beta 1$ ) increased HOTAIR expression and triggered EMT formation. Conversely, blockade of HOTAIR reversed the TGF- $\beta 1$-induced EMT and reduced the colony-forming capacity of breast cancer cells. This result indicated that HOTAIR was involved in multiple signaling pathways in EMT in breast cancer cells [70]. In a recent correlational study between HOTAIR and anti-apoptotic protein Bcl-w in breast cancer tissues, HOTAIR increased the expression of Bcl-w by sequestering miR-206 at the post-transcriptional level in breast cancer cells. This finding provided new insights into the mechanism of breast cancer mediated by HOTAIR [71]. Notably, in contrast to widely known studies in which HOTAIR was overexpressed in the majority of cancer types and played a key role in gene silencing via direct PRC2 recruitment, a report indicated that overexpression of HOTAIR led to subtle transcriptomic changes independent of PRC2 recruitment in breast cancer cells; this result suggests that HOTAIR-mediated transcriptional repression might not require PRC2 [10]. The reasons for the discrepancy with previous reports remain undetermined, requiring further experiments. From what have been discussed, HOTAIR may be a valuable predictor and a potential target for treatment of breast cancer. However, the biological functions and detailed mechanisms of HOTAIR may not be fully understood. More in-depth studies with large sample sizes are needed to understand the role of HOTAIR and elucidate the molecular mechanisms that facilitate more tumor-specific treatment options for patients with breast cancer.

\section{HOTAIR in gastric cancer}

Gastric cancer (GC) ranks as the most common cancer worldwide, with relatively poor prognosis because of the lack of appropriate biomarkers. LncRNAs have been shown to be potentially valuable in GC diagnosis and prognosis evaluation. HOTAIR is one of the most widely studied lncRNAs at the preclinical level and has been recognized as a potent prognostic biomarker for major malignancies, including GC [72-74]. HOTAIR expression was higher in GC tissues than in the adjacent noncancerous tissues and was significantly correlated with lymph node metastasis, TNM stage, and invasion. High HOTAIR expression was also used as a predictor of poor overall survival in patients with GC $[75,76]$. Inhibition of HOTAIR could reduce invasiveness and reverse EMT in GC cells by regulating the transcription factor snail and other epithelial markers, such as E-cadherin, vimentin, and 


\section{Cellular Physiology Cell Physiol Biochem 2018;47:893-913 \\ \begin{tabular}{l|l|l} 
and BiOChemistry & $\begin{array}{l}\text { DOI: 10.1159/000490131 } \\
\text { Published online: May 29, } 2018\end{array}$ & $\begin{array}{l}\text { C } 2018 \text { The Author(s). Published by S. Karger AG, Basel } \\
\text { www.karger.com/cpb }\end{array}$
\end{tabular} \\ Tang/Hann: HOTAIR in Human Cancer}

$\mathrm{N}$-cadherin [76]. HOTAIR promoted cisplatin resistance in GC by targeting miR-126 to activate the phosphatidylinositol 3-kinase (PI3-K)/Akt/multidrug resistance-associated protein 1 (MRP1) genes. Specifically, HOTAIR was shown to directly bind to and inhibit miR126, thereby promoting the expression of vascular endothelial growth factor A (VEGFA) and PI3-K regulatory subunit beta. Thus, HOTAIR acted as a competitive endogenous RNA to promote cisplatin resistance in GC [77]. A high HOTAIR expression level was observed in GC cells, and the antitumor effect of dioscin, a natural steroid saponin extracted from the roots of Polygonatum zanlanscianense, partly depended on the suppression of HOTAIR [78]. HOTAIR unregulated the expression of human leukocyte antigen (HLA)-G by inhibiting miR152 levels. Thus, targeting HOTAIR could be a potential immunotherapy for better prognosis and improved survival in patients with GC [79]. In addition, HOTAIR binds to the multiprotein chromatin modifying complex PRC2, which is responsible for $\mathrm{H} 3 \mathrm{~K} 27 \mathrm{me} 3$, an epigenetic hallmark of repressed chromatin, thereby repressing further the expression of miR-34a in GC [80]. Thus, HOTAIR be a potential prognostic biomarker and target for therapies in patients with GC. Polymorphisms of HOTAIR were also associated with GC susceptibility. For example, an increased risk for HOTAIR rs4759314 A>G polymorphism was determined in the GC group [81]. In addition, one study consisting of 5025 patients with cancer and 5657 controls showed that the rs4759314 polymorphism A allelic gene of HOTAIR was associated with a lower risk of GC, whereas the G allelic gene could be a genetic susceptibility factor for GC in the Chinese population [82]. SNP rs4759314 was also significantly associated with increased risk of GC. Further functional experiments revealed allele-specific effects on HOTAIR expression in GC tissues; individuals with the AG genotype showed higher HOTAIR expression compared with those carrying the AA genotype, Nevertheless, whether HOTAIR SNP rs4759314 could act as a biomarker for predicting GC occurrence has yet to be determined [83]. Overall, accumulating evidence indicated that HOTAIR, which is present in tissues, blood, and gastric juice, was dysregulated in GC and related to tumorigenesis, metastasis, and progression, exhibiting potential as a biomarker for the diagnosis and prognosis of GC.

\section{HOTAIR in colorectal cancer}

Colorectal cancer (CRC) is one of the most frequently diagnosed types of cancer and the third most fatal malignancy worldwide. In recent years, lncRNAs have been found to mediate the proliferation and progression of CRC and is involved in the tumor pathogenesis of CRC. Upregulation of HOTAIR in the primary tumors and blood of patients with CRC was associated with unfavorable prognosis, suggesting that HOTAIR can be used as a potential biomarker in sporadic CRC [84]. Increased HOTAIR expression was significantly associated with invasion, metastasis, and differentiation. Patients with CRC exhibiting high HOTAIR expression showed higher recurrence rates as well as lower metastasis-free and overall survival (OS), compared with patients exhibiting low levels of HOTAIR expression [85, 86]. HOTAIR also significantly promoted migration and invasion in vitro in CRC cells by reducing the expression of E-cadherin while increasing the expression levels of vimentin and MMP-9, a member of the matrix metalloproteinase family involved in the invasion and metastasis of cancer cells [85]. A study showed that miR-545 played an important role in the negative regulation of CRC cell proliferation, which was associated with the expression of EGF-R, a target of miR-545. High HOTAIR expression levels inhibited miR-545, thereby increasing CRC cell proliferation [87]. Reduced levels of HOTAIR expression led to a decrease in the survival of human CRC stem cells, and knockdown of HOTAIR suppressed CRC proliferation, colony formation, migration, and invasion. In particular, downregulation of HOTAIR expression improved radiosensitivity in CRC $[88,89]$. One major reason for the failure of CRC treatment is the occurrence of chemoresistance; silencing of HOTAIR reversed fluoropyrimidinebased chemoresistance by increasing miR-218 expression and inactivating transcription factor nuclear factor-kappaB (NF- $\mathrm{KB}$ ) signaling. Moreover, a high HOTAIR expression level was associated with poor response to 5FU treatment, thus, HOTAIR contributed to 5FU resistance by suppressing miR-218 and activating NF- $\kappa B$ signaling in CRC cells [90]. Genetic 


\section{Cellular Physiology Cell Physiol Biochem 2018;47:893-913 \\ \begin{tabular}{l|l} 
and Biochemistry Published online: May 29, 2018 & $\begin{array}{l}\text { (c) 2018 The Author(s). Published by S. Karger AG, Basel } \\
\text { www.karger.com/cpb }\end{array}$ \\
\hline
\end{tabular} \\ Tang/Hann: HOTAIR in Human Cancer}

variants of HOTAIR were also associated with the risk of human CRC, similar to other types of cancer. A case-control study evaluated the association between HOTAIR SNPs and the risk of CRC; individuals with the rs7958904 CC genotype showed a significantly decreased risk of CRC in both stage 1 and stage 2, compared with those carrying the GG genotype [91]. Collectively, the current data supported the role of HOTAIR in the diagnosis and prognosis of patients with CRC as well as its potentially therapeutic use in CRC. However, a significant discrepancy remains in understanding the function of HOTAIR in CRC, particularly the initiation, development, and progression of CRC. Thus, more efforts are need to be directed toward elucidating the underlying mechanisms of HOTAIR.

\section{HOTAIR in cervical cancer}

LncRNAs have recently been implicated in the pathogenesis of many types of cancer, including gynecological tumors.Cervical cancer $(\mathrm{CaCx})$ is considered the second highest contributor to the number of deaths in female malignancies, exceeded only by breast cancer and carrying high risks of morbidity and mortality. Thus, novel treatment targets and prognosis biomarkers need to be identified to improve the survival of patients with CaCx. Many IncRNAs emerged as pivotal regulators in various biological processes and played important roles in oncogenesis and progression of $\mathrm{CaCx}$ [92]. High HOTAIR expression in $\mathrm{CaCx}$ was significantly correlated with progression and poor prognosis, and elevated HOTAIR expression could induce radioresistance by inhibiting p21; this finding indicates that targeting HOTAIR is a potential therapeutic strategy in CaCx [93]. HOTAIR expression in the sera was significantly increased in patients with $\mathrm{CaCx}$ relative to that in normal controls. Elevated HOTAIR was associated with advanced tumor stage, lymphatic node metastasis, recurrence, and short OS. Thus, circulating HOTAIR may be used as a potent prognostic marker in patients with $\mathrm{CaCx}$ [94-96]. Loss-of-function experiments indicated that overexpression of HOTAIR promoted, whereas silencing of HOTAIR inhibited growth, invasion, and cell viability of $\mathrm{CaCx}$ cells in vitro and in vivo. Moreover, HOTAIR modulated the expression of human leucocyte antigen-G by competitively binding to miR-148a; this effect suggests that HOTAIR played an important oncogenic role in $\mathrm{CaCx}$ and might serve as a biomarker and a potential target to determine prognosis, as well as a therapeutic intervention for $\mathrm{CaCx}$ [96]. Pearson's correlation analysis indicated the negative correlation between the expression levels of miR-17-5p and HOTAIR. The luciferase reporter assay revealed that miR-17-5p directly targeted HOTAIR 3'-UTR, thereby controlling the growth of $\mathrm{CaCx}$. Thus, targeting the tumor promoter HOTAIR in $\mathrm{CaCx}$ might provide a novel therapeutic target for the future treatment of $\mathrm{CaCx}$ [97]. Propofol, one of the extensively and commonly used intravenous anesthetic agents, reportedly played a role as an antitumor in various cancers, including $\mathrm{CaCx}$. One report found that propofol significantly decreased viability and increased apoptosis, which were overcome by the overexpression of HOTAIR in CaCx cells. Moreover, exogenously expressed HOTAIR could resist the propofol-reduced expression of mTOR/p70S6K proteins, widely known Ser/Thr kinases that regulate cell growth, proliferation, survival, autophagy, and metabolism, among other functions. Similar results were observed in an animal study in which propofol inhibited tumor size and cell viability and promoted cell apoptosis via the HOTAIR-mediated inhibition of the mTOR/ p70S6K pathway in $\mathrm{CaCx}$ [98]. In the evaluation of the association between 3 haplotypetagging SNPs (rs920778, rs1899663 and rs4759314) in HOTAIR and the risk of CaCx, the SNP rs920778 in the intronic enhancer of HOTAIR was strongly associated with $\mathrm{CaCx}$, and high HOTAIR expression was associated with the risk-associated allele $\mathrm{T}$ [99]; these results confirmed that functional SNP rs920778 regulated HOTAIR expression and might ultimately influence the predisposition for $\mathrm{CaCx}$ [99]. In addition, 1209 cases of $\mathrm{CaCx}$ and 1348 controls were enrolled in a study using the TaqMan allelic discrimination method and the Cancer Genome Atlas (TCGA) database for analysis of allele-specific HOTAIR expression. A relation was found between the rs7958904 CC genotype and increased risk of CaCx relative to that of the GG/GC genotypes. The analysis using TCGA data indicated that CC tissues with the rs7958904 CC genotype exhibited higher HOTAIR expression compared with those 


\section{Cellular Physiology Cell Physiol Biochem 2018;47:893-913 \\ and Biochemistry Published online: May 29, $2018 \quad \begin{aligned} & \text { DOI: 10.1159/000490131 } 2018 \text { The Author(s). Published by S. Karger AG, Basel } \\ & \text { www.karger.com/cpb }\end{aligned}$ \\ Tang/Hann: HOTAIR in Human Cancer}

carrying the GG genotype. Thus, HOTAIR rs7958904 could influence CC susceptibility, and HOTAIR could be used as a diagnostic biomarker [100]. Another report demonstrated that the genetic variant exhibited an alteration in secondary structure propensities and a gain of a miR-22 binding site in HOTAIR, which was found to be concordant with the overexpression of miR-22 in low HOTAIR cases, compared with that in the control. Moreover, miR-22 expression was negatively correlated with HOTAIR and human papillomavirus (HPV) E7 oncogene expression in HPV16-positive cases and E7 transfected HPV-negative cells; this finding suggests that HOTAIR rs2366152C not only has the potential to serve as a marker for singling out $\mathrm{CaCx}$ cases lacking metastatic molecular signatures but also to explain the functional inactivation of HOTAIR in these cases [101]. Regardless, further studies are required to confirm this finding.

\section{HOTAIR in ovarian cancer}

Ovarian cancer (OC) is the most deadly gynecological malignancy. Many lncRNAs are aberrantly expressed in OC and may serve as prognostic markers. HOTAIR expression was higher in epithelial OC tissues than in benign ones and was highly correlated with the stages, histological grades, lymph node metastasis, reduced OS, and disease-free survival (DFS). Thus, HOTAIR could be a novel prognostic marker and a potential therapeutic target in patients with OC [102]. HOTAIR expression predicted a poor outcome in carboplatin-treated patients with OC. Knockdown of HOTAIR suppressed cell proliferation, reduced invasiveness, and restored cisplatin sensitivity by enhancing cisplatin-induced cytotoxicity and apoptosis in OC cells [103]. Accordingly, increased HOTAIR-induced platinum resistance in OC and high HOTAIR expression were observed in recurrent platinum-resistant OC relative to those in primary ovarian tumors $[104,105]$. All of these findings show that HOTAIR was an independent prognostic factor for predicting OS in patients with OC. A recent meta-analysis indicated that IncRNAs, including HOTAIR, could function as potential prognostic markers for patients with OC and that high HOTAIR expression was associated with shorter OS in OC [106]. Mechanistically, the results demonstrated that ectopic HOTAIR expression induced the activation of NF- $\kappa$ B signaling during DNA damage response (DDR) and induced the expression of the key NF- $\kappa B$ target gene interleukin-6 [106]; these actions indicate the critical role of HOTAIR in cellular senescence and platinum sensitivity. Thus, the NF- $\kappa B-H O T A I R$ regulatory axis triggered a positive-feedback loop cascade during DDR and contributed to cellular senescence as well as chemotherapy resistance in ovarian and other types of cancer [107]. Interaction with kinases, such as mitogen-activated protein kinase 1 (MAPK1), regulated the growth, migration, and invasion of OC cells [108]. Overexpression of HOTAIR promoted the progression, proliferation, and chemoresistance of the cell cycle by activating the Wnt/ $\beta$ catenin pathway in OC cells [109]. In one study, a peptide nucleic acid (PNA)-based approach was found to hinder the interaction of HOTAIR with EZH2, inhibiting the HOTAIR-EZH2 associated pathway and re-sensitized resistant OC to platinum; treatment of OC cells with overexpressed HOTAIR with PNAs decreased invasiveness and increased chemosensitivity, which were correlated with reduced activation and decreased expression of the NF- $\kappa B$ target genes MMP-9 and interleukin 6. These observations indicate a novel therapeutic approach in the treatment of OC [110]. Another study reported that HOTAIR expression or its surrogate DNAme signature could predicate poor outcome in carboplatin-treated patients with OC, further indicating that HOTAIR could be used as a potential biomarker and is a novel target to overcome carboplatin resistance in patients with OC [103]. In addition, the TT genotype and $\mathrm{T}$ allele of HOTAIR rs 920778 were significantly associated with a reduction in OC risk. Moreover, TT and TC carriers showed a shorter OS. These findings imply that HOTAIR rs920778 polymorphism could influence OC susceptibility and prognosis; however, further research has to be undertaken [19].

\section{HOTAIR in endometrial carcinoma}

Endometrial carcinoma (EC) is the second most common form of gynecological malignancy and is associated with deregulated IncRNAs with specific biological functions of 


\section{Cellular Physiology Cell Physiol Biochem 2018;47:893-913 \\ and Biochemistry Published online:May 29, $2018 \quad$\begin{tabular}{l|l} 
DOI: 10.1159/000490131 & $\begin{array}{l}\text { (c) } 2018 \text { The Author(s). Published by S. Karger AG, Basel } \\
\text { www.karger.com/cpb }\end{array}$
\end{tabular} \\ Tang/Hann: HOTAIR in Human Cancer}

tumor cells [52]. HOTAIR expression in EC tissues was significantly increased relative to that in normal tissues, and high HOTAIR expression was positively correlated with metastasis and shortened OS in EC. In addition, a significant association between HOTAIR expression and the EC grade and lymph node metastasis suggested that HOTAIR could be used as a novel prognostic biomarker in patients with EC [111]. Depletion of HOTAIR in vivo significantly suppressed endometrial tumorigenesis and reduced the size of tumors [52, 111, 112]. Knockdown of HOTAIR substantially inhibited proliferation, migration, invasion, and remarkable G0/G1 phase arrest in EC cells. Accordingly, a study in vitro found that silencing of HOTAIR significantly inhibited tumor growth in a xenograft mouse model [111]. In identifying whether HOTAIR participating in the regulation of cisplatin-resistant induced autophagy in EC cells, one study observed that silencing of HOTAIR reduced the proliferation and enhanced the autophagic activity of cisplatin-resistant Ishikawa cells. In addition, HOTAIR regulated the cisplatin resistance of human EC cells via autophagy regulation by influencing Beclin-1 expression, multidrug resistance, and P-glycoprotein [113].

Overall, HOTAIR may be a predictor of poor prognosis in all estrogen-dependent tumors, specifically the cervical, ovarian, and endometrial types of cancer with distinct mechanisms associated. Future well-designed and larger-scale studies are needed to validate these findings. More experiments are required to determine the true functions of HOTAIR in tumorigenesis in these malignancies, which may constitute those of a therapeutic target and a biomarker aimed at improving therapeutic outcomes.

\section{HOTAIR in head and neck cancer}

Head and neck cancer, the sixth most common cancer worldwide with high recurrence, metastasis, and poor treatment outcome, consists of carcinomas arising from the mucosal epithelia of the head and neck region as well as various cell types of salivary glands, and the thyroid [114]. The potential of HOTAIR as a therapeutic target in head and neck squamous cell carcinoma (HNSCC) remain undetermined. HOTAIR depletion induced tumor cell apoptosis via the mitochondrial cell death pathway (e.g., Bcl-2, BAX, Caspase-3, Cleaved Caspase-3, Cytochrome c) in HNSCC cells, suggesting that inhibition of HOTAIR could be developed as a new therapeutic target in the treatment of HNSCC [115]. Knockdown of HOTAIR and Hu antigen R(HuR), a ubiquitous RNA-binding protein that influences the stability and translation of several cellular mRNAs and one of the most widely studied regulators of eukaryotic posttranscriptional gene expression [116], decreased cell viability, cellular migration, and invasion. The expression levels of HuR and HOTAIR were positively correlated, and exhibited significantly high expression levels in tumors. These results show the existence of a regulatory loop in which the expression levels of HOTAIR and HuR were reciprocally regulated during the metastasis and progression of HNSCC [117]. HOTAIR expression also increased in oral squamous cell carcinoma (OSCC) and was associated with metastasis, stages, and histological differentiation. In addition, overexpression of HOTAIR indicated poor OS and DFS in patients with OSCC. By contrast, knockdown of HOTAIR decreased cell proliferation and colony formation, cell invasion, and migration and induced apoptosis in OSCC cells. Another study reported that HOTAIR was highly expressed in OSCC tissues and facilitated the growth of OSCC cells. Relative HOTAIR expression was correlated with tumor size and clinical stage. HOTAIR expression was higher in OSCC cells than in normal oral epithelial cells, which be used as an eligible diagnostic and prognostic molecular marker in OSCC [118]. In addition, a significant negative correlation was determined between the expression levels of HOTAIR and E-cadherin in OSCC tissues and cells: HOTAIR contributed to the regulation of E-cadherin by binding to EZH2 and H3K27me3 in the E-cadherin gene promoter. These findings suggest that HOTAIR expression could be one of the critical targets in progression and metastasis, as well as an indicator of poor survival in OSCC [119]. A recent study demonstrated that silencing of HOTAIR significantly inhibited OCSC stemness, invasiveness and tumourigenicity in xenograft mouse models; by contrast, excessive HOTAIR expression enhanced the metastatic potential and EMT characteristics in OSCC. This finding suggests that HOTAIR was a potential predictor of poor survival in patients with OSCC and could be used as a therapeutic target 


\section{Cellular Physiology Cell Physiol Biochem 2018;47:893-913 \\ and Biochemistry Published online: May 29, $2018 \quad$\begin{tabular}{l|l} 
DOI: 10.1159/000490131 2018 The Author(s). Published by S. Karger AG, Basel \\
www.karger.com/cpb
\end{tabular} \\ Tang/Hann: HOTAIR in Human Cancer}

in OSCC [120]. Human nasopharyngeal carcinoma (NPC) is a distinct type of head and neck cancer, occurring at a high frequency in southern China, Southeast Asia, and North Africa. Emerging studies show that lncRNAs play critical roles in carcinogenesis and progression. However, the roles and mechanisms of aberrantly expressed lncRNAs in the pathogenesis of NPC are not fully understood. HOTAIR expression was extremely high in NPC cells and clinical samples $[121,122]$, high expression levels of HOTAIR are correlated with poor prognosis in patients with NPC, and HOTAIR mediates the migration and invasion of NPC cells [122]. HOTAIR also promoted angiogenesis by directly activating the GRP78-mediated expression levels of the angiogenic factor VEGFA and Ang2 ( a member of the angiopoietin (Ang) family) in NPC cells [121]. Expression of fatty acid synthase (FASN) was positively correlated with that of HOTAIR in NPC samples, and knockdown of HOTAIR led to a decrease in FASN protein expression in NPC cells, thereby inhibiting cell growth and invasion [123]. Serum exosomal miR-21 and HOTAIR were significantly correlated with the clinical parameters of laryngeal squamous cell carcinoma (LSCC) and combined evaluation of their serum expressions may be considered a valuable biomarker and promising predicting tool for LSCC [124]. HOTAIR also played an oncogenic role in human LSCC. HOTAIR levels were significantly higher in LSCC than in corresponding adjacent non-neoplastic tissues; patients with poor histological grade or advanced clinical stage exhibited higher HOTAIR expression. The log-rank test in one study showed a significant association between high HOTAIR expression and poor prognosis in patients with LSCC. Multivariate Cox analysis suggested that HOTAIR was an independent prognostic factor for LSCC outcome. Thus, HOTAIR could serve as a biomarker and potential target for therapeutic intervention in LSCC [125]. HOTAIR and the core component of PRC2 EZH2 were overexpressed in LSCC tissues, and reduction of HOTAIR expression stimulated EZH2 expression, promoting proliferation and increasing sensitivity to cis-platinum in LSCC cells [126].

\section{HOTAIR in esophageal and papillary thyroid carcinoma}

Studies indicated that HOTAIR expression was significantly induced in esophageal squamous cell carcinoma (ESCC). In one study, patients with ESCC who exhibited high HOTAIR expression showed a significantly poorer prognosis than those who exhibited low HOTAIR expression [127]. Moreover, HOTAIR promoted the migration and invasion of ESCC cells in vitro. Mechanistically, HOTAIR directly decreased the expression of Wnt inhibitory factor-1 (WIF-1), a secreted antagonist that binds Wnt ligands by promoting histone H3K27 methylation in the promoter region, and activated the Wnt/ $\beta$-catenin signaling pathway. The HOTAIR/WIF-1 axis revealed the molecular mechanism of metastasis and represented a novel therapeutic target in patients with ESCC [127]. Data analysis from several studies indicated that HOTAIR-mediated gene regulation played a critical role in ESCC progression and was a novel epigenetic molecular therapeutic target for ESCC. Thus, HOTAIR is a novel molecule involved in the progression and prognosis of ESCC. Several studies also found that serum HOTAIR might be used as a potential biomarker for the diagnosis and progression of ESCC [128-132]. The correlation and significance of HOTAIR and EMTrelated factors in the occurrence and metastasis of ESCC progression were also evaluated. HOTAIR was positively correlated with Snail but negatively correlated with E-cadherin expression. HOTAIR could then be involved in the induction of EMT-related factors and thus associated with carcinogenesis and metastasis in patients with ESCC [133]. The functional SNP in HOTAIR may affect the expression and/or function of HOTAIR and is thus linked to the risk of ESCC occurrence. Allelic regulation of rs920778 on HOTAIR expression was observed in ESCC cells and normal esophageal tissue specimens, similar to other tumors, with a higher level of HOTAIR expression observed among the T allele carriers. These results demonstrate that functional genetic variants influencing lncRNA regulation might explain a fraction of ESCC genetic basis [134]. Together, these findings indicate that full elucidation of HOTAIR functionalities relevant to ESCC may provide opportunities for the use of IncRNAs (such as HOTAIR) in identifying novel drug targets and therapies for ESCC. The role of HOTAIR and its functional SNPs in papillary thyroid carcinoma (PTC) has also been investigated. One 


\section{Cellular Physiology Cell Physiol Biochem 2018;47:893-913

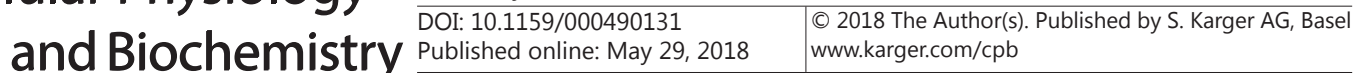 \\ Tang/Hann: HOTAIR in Human Cancer}

study showed that HOTAIR expression was higher in PTC tissues than in normal tissues. A series of gain-loss assays demonstrated that HOTAIR acted as a PTC oncogene by promoting the tumorigenic properties of PTC cells, suggesting that HOTAIR could be considered a promising candidate as a diagnostic and prognostic biomarker and for the development of novel therapeutic approaches. In addition, the functional HOTAIR rs920778 genetic variant was reported to exhibit SNP of PTC susceptibility; this finding also indicates that SNPs could influence lncRNA expression, which may explain part of PTC genetic basis [135]. Nevertheless, the precise molecular roles of HOTAIR justify the need for further characterization.

\section{HOTAIR in hematologic malignancies}

\section{HOTAIR in acute myeloid leukemia}

Hematologic diseases affect people of all ages worldwide. In the recent decade, significant progress has been made in diagnostic and therapeutic strategies in hematology. Numerous studies have been conducted on IncRNAs, which function in the development of blood cells by regulating blood cell fates via epigenetic control of gene expression. Several lncRNAs and their targets become dysregulated during malignant hematopoiesis [136]. Among these lncRNAs, HOTAIR plays an important role in the development of many types of cancers, including acute myeloid leukemia (AML), chronic lymphocytic leukemia, and multiple myeloma, among others [137]. Relative to that of patients with low HOTAIR expression, the OS of patients with AML showing high HOTAIR expression was significantly reduced. In addition, the expression of the downstream genes of HOTAIR signaling, including EZH2, LSD1, DNMT3A, and DNMT3B, was also increased in patients with AML, demonstrating a significant positive correlation with high HOTAIR expression [138]. HOTAIR was highly expressed in patients with de novo AML relative to those in patients with AML-complete remission (CR) and normal controls. In addition, HOTAIR was significantly correlated with clinical-pathological prognostic stratification, leukemic burden, DFS, and OS in AML. Thus, HOTAIR can represent a potential biomarker of poor prognosis and a potential therapeutic target for AML treatment $[139,140]$. Mechanistically, silencing of HOTAIR inhibited cell growth, induced apoptosis, and decreased number of colony-forming cells in AML. Moreover, HOTAIR regulated the expression of c-KIT, a type III receptor tyrosine kinase, by competitively binding to miR-193a; this action confirms that HOTAIR played an important oncogenic role in AML and could serve as a marker and a potential target for therapeutic intervention in AML [141]. Notably, a recent report indicated that HOTAIR might not be an informative and reliable biomarker for AML diagnosis. Thus, more studies should be conducted to confirm the differences in the expression levels of HOTAIR between patients with AML and healthy individuals, as well as to clarify conflicting findings [142]. Blockade of HOTAIR myeloid 1 (HOTAIRM1), a human HOXA gene cluster and a novel myeloid-specific lncRNA, resulted in the retained expression of many otherwise all-trans retinoic acid (ATRA)-induced cell cycle and DNA replication genes, abated ATRA induction of cell surface leukocyte activation, defense response, and other maturation-related molecules, all of which were accompanied by the retained expression of the alpha-4-integrin gene (ITGA4) (CD49d) and decreased induction of integrin alpha X (ITGAX) (CD11c) in NB4 acute promyelocytic leukemia cells. These results indicate that HOTAIRM1 provided a regulatory link among those genes in myeloid acute promyelocytic leukemia cell maturation by modulating integrin-controlled cell cycle progression at the transcriptional level [143].

\section{HOTAIR in diffuse large B-cell lymphoma and chronic myelogenous leukemia}

Diffuse large B-cell lymphoma (DLBCL) is one of the most common types of malignancy worldwide. Lack of clear symptoms and early detection make DLBCL difficult to diagnose early, leading to poor prognosis. A study showed that high HOTAIR expression in DLBCL tumor tissues and cells was strongly correlated with tumor size, clinical stage, symptoms, and prognostic index scores. Moreover, silencing of HOTAIR inhibited growth, induced cell 


\section{Cellular Physiology Cell Physiol Biochem 2018;47:893-913

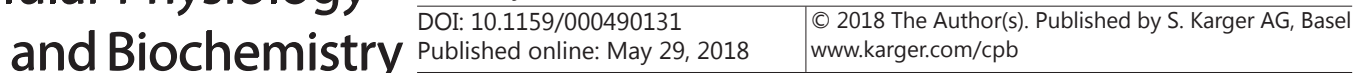 \\ Tang/Hann: HOTAIR in Human Cancer}

cycle arrest, and apoptosis via the PI3K/Akt/NF- $\kappa B$ pathways, suggesting that HOTAIR can be used as a novel marker and potential target for gene therapy in the treatment of DLBCL [144]. Imatinib, a breakpoint cluster region-Abelson murine leukemia tyrosine kinase inhibitor, has been used to treat chronic myelogenous leukemia (CML)[145]. LncRNA HOTAIR was considerably upregulated in patients with highly expressed MRP1 as well as in imatinibresistant cells. Knockdown of HOTAIR inhibited MRP1 expression in K562-imatinib cells and resulted in increased sensitivity to imatinib treatment. In addition, activation of the PI3K/ Akt signaling pathway was markedly reduced when the HOTAIR gene was silenced in K562imatinib cells. These findings indicate that knockdown of HOTAIR played a crucial role in improving acquired resistance to imatinib in CML K562-R cells via the PI3K/Akt pathway [146].

Overall, although HOTAIR was involved in the development and progression of this type of malignancy and was associated with a poor clinical-pathologic prognostic stratification, the exact function and mechanism have yet to be elucidated. Numerous studies need to be conducted to further determine the role of HOTAIR in hematologic malignancies. LncRNAs such as HOTAIR may be useful as markers for the diagnosis and prognosis of cancer and as potential targets for novel therapies.

\section{Conclusion}

The application of next-generation sequencing to a growing number of cancer transcriptomes has revealed thousands of lncRNAs in which aberrant expressions are associated with oncogenesis progression and development of different cancer types; however, few have been functionally characterized. Studies in recent years led to significant progress in understanding the biology of lncRNA, including HOTAIR, and even in the development of potential biomarkers and therapeutic application. Regardless, the expression and function of HOTAIR in many human cancers remain undetermined. Further research has to be conducted to reveal the underlying role of HOTAIR in the occurrence, progression, and metastasis of cancer. Biomarker-driven personalized cancer therapy has recently drawn increased attention, and several technologies have been developed to detect biomarkers for predicting the response of cancer to particular therapies. With the use of innovative technologies, lncRNAs may currently be used as biomarkers in the diagnosis and prognosis of diseases, including cancer. Among these, circulating lncRNAs, such as HOTAIR, in patients with cancer have been used to diagnose early-stage tumors after surgical resection, chemotherapy/radiation treatment, and metastatic relapse. In addition, the potential role of HOTAIR polymorphisms as predictive or therapeutic biomarkers in cancer needs to be carefully evaluated and verified using further studies.

Overall, the mechanism of action of HOTAIR is more complicated than we thought and thus needs to be fully determined. We believe that further insights into the biological functions of HOTAIR in tumor pathogenesis can provide an in-depth understanding of the malignancies by aiding in the identification of essential disease processes to provide useful therapeutic and prognostic biomarkers for cancer patients. Moreover, studies to elucidate the molecular mechanisms underlying the expression and regulation of HOTAIR, such as the biochemical and structural nature of HOTAIR-protein and HOTAIR-DNA interactions may offer promise for the development of potential therapeutic strategies for major types of human cancer in the future.

\section{Acknowledgements}

This work was supported in part by grants from the National Nature Scientific Foundation of China (Nos. 81272614, 81403216, and 81703551), Science and Technology Program of Guangzhou (No. 201607010385), Discipline of Integrated Chinese and Western 


\section{Cellular Physiology Cell Physiol Biochem 2018;47:893-913

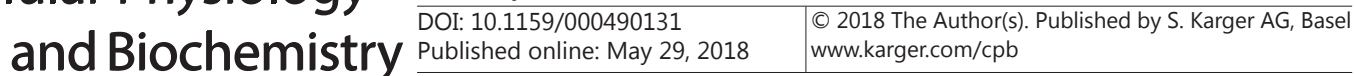 Tang/Hann: HOTAIR in Human Cancer}

Medicine in Guangzhou University of Chinese Medicine (No. A1-Af-D018161Z1513), Special Science and Technology Join Fund from Guangdong Provincial Department of Science and Technology-Guangdong Academy of Traditional Chinese Medicine (Nos. 2014A020221024, 2017A050506042), and Specific Research Fund for TCM Science and Technology of Guangdong Provincial Hospital of Chinese Medicine (Nos. YK2013B2N13, YN2015MS19).

\section{Disclosure Statement}

The authors claim no conflict of interests.

\section{References}

Woo CJ, Kingston RE: Hotair lifts noncoding rnas to new levels. Cell 2007;129:1257-1259.

Chu C, Qu K, Zhong FL, Artandi SE, Chang HY: Genomic maps of long noncoding rna occupancy reveal principles of rna-chromatin interactions. Mol Cell 2011;44:667-678.

3 Gupta RA, Shah N, Wang KC, Kim J, Horlings HM, Wong DJ, Tsai MC, Hung T, Argani P, Rinn JL, Wang Y, Brzoska P, Kong B, Li R, West RB, van de Vijver MJ, Sukumar S, Chang HY: Long non-coding rna hotair reprograms chromatin state to promote cancer metastasis. Nature 2010;464:1071-1076.

-4 Bhan A, Mandal SS: Long noncoding rnas: Emerging stars in gene regulation, epigenetics and human disease. ChemMedChem 2014;9:1932-1956.

-5 Rinn JL, Kertesz M, Wang JK, Squazzo SL, Xu X, Brugmann SA, Goodnough LH, Helms JA, Farnham PJ, Segal E, Chang HY: Functional demarcation of active and silent chromatin domains in human hox loci by noncoding rnas. Cell 2007;129:1311-1323.

6 Wang L, Zeng X, Chen S, Ding L, Zhong J, Zhao JC, Wang L, Sarver A, Koller A, Zhi J, Ma Y, Yu J, Chen J, Huang H: Brca1 is a negative modulator of the prc2 complex. EMBO J 2013;32:1584-1597.

-7 Tsai MC, Manor O, Wan Y, Mosammaparast N, Wang JK, Lan F, Shi Y, Segal E, Chang HY: Long noncoding rna as modular scaffold of histone modification complexes. Science 2010;329:689-693.

-8 Marchese FP, Huarte M: Long non-coding rnas and chromatin modifiers: Their place in the epigenetic code. Epigenetics 2014;9:21-26.

-9 Bhan A, Mandal SS: Lncrna hotair: A master regulator of chromatin dynamics and cancer. Biochim Biophys Acta 2015;1856:151-164.

-10 Portoso M, Ragazzini R, Brencic Z, Moiani A, Michaud A, Vassilev I, Wassef M, Servant N, Sargueil B, Margueron R: Prc2 is dispensable for hotair-mediated transcriptional repression. EMBO J 2017;36:981994.

11 Shi J, Dong B, Cao J, Mao Y, Guan W, Peng Y, Wang S: Long non-coding rna in glioma: Signaling pathways. Oncotarget 2017;8:27582-27592.

12 Wu Y, Xiong Q Li S, Yang X, Ge F: Integrated proteomic and transcriptomic analysis reveals long noncoding rna hox transcript antisense intergenic rna (hotair) promotes hepatocellular carcinoma cell proliferation by regulating opioid growth factor receptor (ogfr). Mol Cell Proteomics 2018;17:146-159.

13 Cheng C, Qin Y, Zhi Q Wang J, Qin C: Knockdown of long non-coding rna hotair inhibits cisplatin resistance of gastric cancer cells through inhibiting the pi3k/akt and wnt/beta-catenin signaling pathways by upregulating mir-34a. Int J Biol Macromol 2018;107:2620-2629.

-14 Fu WM, Lu YF, Hu BG, Liang WC, Zhu X, Yang HD, Li G, Zhang JF: Long noncoding rna hotair mediated angiogenesis in nasopharyngeal carcinoma by direct and indirect signaling pathways. Oncotarget 2016;7:4712-4723.

15 Chen J, Lin C, Yong W, Ye Y, Huang Z: Calycosin and genistein induce apoptosis by inactivation of hotair/pakt signaling pathway in human breast cancer mcf-7 cells. Cell Physiol Biochem 2015;35:722-728.

16 Lv Z, Xu Q Yuan Y: A systematic review and meta-analysis of the association between long non-coding rna polymorphisms and cancer risk. Mutat Res 2017;771:1-14.

-17 Zhang ZX, Tong X, Zhang WN, Fu WN: Association between the hotair polymorphisms and cancer risk: An updated meta-analysis. Oncotarget 2017;8:4460-4470.

18 Bayram S, Sumbul AT, Dadas E: A functional hotair rs12826786 c >t polymorphism is associated with breast cancer susceptibility and poor clinicopathological characteristics in a turkish population: A hospital-based case-control study. Tumour Biol 2016;37:5577-5584. 


\section{Cellular Physiology Cell Physiol Biochem 2018;47:893-913 \begin{tabular}{l|l} 
DOI: 10.1159/000490131 & and Biochemistry \\
Published online: May 29, 2018 & $\begin{array}{l}\text { O 2018 The Author(s). Published by S. Karger AG, Basel } \\
\text { www.karger.com/cpb }\end{array}$
\end{tabular} \\ Tang/Hann: HOTAIR in Human Cancer}

19 Qiu H, Wang X, Guo R, Liu Q, Wang Y, Yuan Z, Li J, Shi H: Hotair rs920778 polymorphism is associated with ovarian cancer susceptibility and poor prognosis in a chinese population. Future Oncol 2017;13:347-355.

20 Taheri M, Habibi M, Noroozi R, Rakhshan A, Sarrafzadeh S, Sayad A, Omrani MD, Ghafouri-Fard S: Hotair genetic variants are associated with prostate cancer and benign prostate hyperplasia in an iranian population. Gene 2017;613:20-24.

21 Nakagawa T, Endo H, Yokoyama M, Abe J, Tamai K, Tanaka N, Sato I, Takahashi S, Kondo T, Satoh K: Large noncoding rna hotair enhances aggressive biological behavior and is associated with short disease-free survival in human non-small cell lung cancer. Biochem Biophys Res Commun 2013;436:319-324.

22 Zhai N, Xia Y, Yin R, Liu J, Gao F: A negative regulation loop of long noncoding rna hotair and p53 in nonsmall-cell lung cancer. Onco Targets Ther 2016;9:5713-5720.

23 Zhang CG, Yin DD, Sun SY, Han L: The use of Incrna analysis for stratification management of prognostic risk in patients with nsclc. Eur Rev Med Pharmacol Sci 2017;21:115-119.

24 Loewen G, Jayawickramarajah J, Zhuo Y, Shan B: Functions of lncrna hotair in lung cancer. J Hematol Oncol 2014;7:90.

25 Wang R, Yan B, Li Z, Jiang Y, Mao C, Wang X, Zhou X: Long non-coding rna hox transcript antisense rna promotes expression of 14-3-3sigma in non-small cell lung cancer. Exp Ther Med 2017;14:4503-4508.

26 Liu XH, Liu ZL, Sun M, Liu J, Wang ZX, De W: The long non-coding rna hotair indicates a poor prognosis and promotes metastasis in non-small cell lung cancer. BMC Cancer 2013;13:464.

27 Kaestner KH: The foxa factors in organogenesis and differentiation. Curr Opin Genet Dev 2010;20:527-532.

28 Wang R, Shi Y, Chen L, Jiang Y, Mao C, Yan B, Liu S, Shan B, Tao Y, Wang X: The ratio of foxa1 to foxa2 in lung adenocarcinoma is regulated by lncrna hotair and chromatin remodeling factor lsh. Sci Rep 2015;5:17826.

29 Li N, Wang Y, Liu X, Luo P, Jing W, Zhu M, Tu J: Identification of circulating long noncoding rna hotair as a novel biomarker for diagnosis and monitoring of non-small cell lung cancer. Technol Cancer Res Treat 2017:1533034617723754.

30 Liu Y, Luo F, Xu Y, Wang B, Zhao Y, Xu W, Shi L, Lu X, Liu Q: Epithelial-mesenchymal transition and cancer stem cells, mediated by a long non-coding rna, hotair, are involved in cell malignant transformation induced by cigarette smoke extract. Toxicol Appl Pharmacol 2015;282:9-19.

-31 Liu Z, Sun M, Lu K, Liu J, Zhang M, Wu W, De W, Wang Z, Wang R: The long noncoding rna hotair contributes to cisplatin resistance of human lung adenocarcinoma cells via downregualtion of p21(waf1/cip1) expression. PLoS One 2013;8:e77293.

-32 Liu MY, Li XQ, Gao TH, Cui Y, Ma N, Zhou Y, Zhang GJ: Elevated hotair expression associated with cisplatin resistance in non-small cell lung cancer patients. J Thorac Dis 2016;8:3314-3322.

33 Li J, Li S, Chen Z, Wang J, Chen Y, Xu Z, Jin M, Yu W: Mir-326 reverses chemoresistance in human lung adenocarcinoma cells by targeting specificity protein 1. Tumour Biol 2016;37:13287-13294.

-34 Wang R, Chen X, Xu T, Xia R, Han L, Chen W, De W, Shu Y: Mir-326 regulates cell proliferation and migration in lung cancer by targeting phox2a and is regulated by hotair. Am J Cancer Res 2016;6:173-186.

-35 Chen J, Shen Z, Zheng Y, Wang S, Mao W: Radiotherapy induced lewis lung cancer cell apoptosis via inactivating beta-catenin mediated by upregulated hotair. Int J Clin Exp Pathol 2015;8:7878-7886.

-36 Yang Z, Zhou L, Wu LM, Lai MC, Xie HY, Zhang F, Zheng SS: Overexpression of long non-coding rna hotair predicts tumor recurrence in hepatocellular carcinoma patients following liver transplantation. Ann Surg Oncol 2011;18:1243-1250.

37 Gao JZ, Li J, Du JL, Li XL: Long non-coding rna hotair is a marker for hepatocellular carcinoma progression and tumor recurrence. Oncol Lett 2016;11:1791-1798.

38 Ishibashi M, Kogo R, Shibata K, Sawada G, Takahashi Y, Kurashige J, Akiyoshi S, Sasaki S, Iwaya T, Sudo T, Sugimachi K, Mimori K, Wakabayashi G, Mori M: Clinical significance of the expression of long non-coding rna hotair in primary hepatocellular carcinoma. Oncol Rep 2013;29:946-950.

-39 An J, Wu M, Xin X, Lin Z, Li X, Zheng Q, Gui X, Li T, Pu H, Li H, Lu D: Inflammatory related gene ikkalpha, ikkbeta, ikkgamma cooperates to determine liver cancer stem cells progression by altering telomere via heterochromatin protein 1-hotair axis. Oncotarget 2016;7:50131-50149.

40 Li H, An J, Wu M, Zheng Q, Gui X, Li T, Pu H, Lu D: Lncrna hotair promotes human liver cancer stem cell malignant growth through downregulation of setd2. Oncotarget 2015;6:27847-27864.

41 Sahasrabuddhe AA: Bmi1: A biomarker of hematologic malignancies. Biomark Cancer 2016;8:65-75.

-42 Fu WM, Zhu X, Wang WM, Lu YF, Hu BG, Wang H, Liang WC, Wang SS, Ko CH, Waye MM, Kung HF, Li G, Zhang JF: Hotair mediates hepatocarcinogenesis through suppressing mirna-218 expression and activating p14 and p16 signaling. J Hepatol 2015;63:886-895. 


\section{Cellular Physiology Cell Physiol Biochem 2018;47:893-913

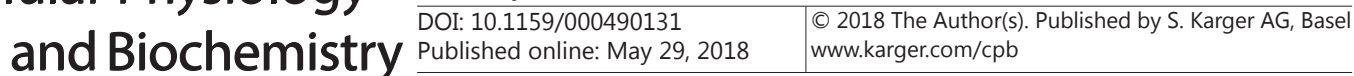 \\ Tang/Hann: HOTAIR in Human Cancer}

43 Ding C, Cheng S, Yang Z, Lv Z, Xiao H, Du C, Peng C, Xie H, Zhou L, Wu J, Zheng S: Long non-coding rna hotair promotes cell migration and invasion via down-regulation of rna binding motif protein 38 in hepatocellular carcinoma cells. Int J Mol Sci 2014;15:4060-4076.

44 Zhou JJ, Cheng D, He XY, Meng Z, Li WZ, Chen RF: Knockdown of hotair suppresses proliferation and cell cycle progression in hepatocellular carcinoma cell by downregulating ccnd1 expression. Mol Med Rep 2017;16:4980-4986.

45 Su DN, Wu SP, Chen HT, He JH: Hotair, a long non-coding rna driver of malignancy whose expression is activated by foxc1, negatively regulates mirna-1 in hepatocellular carcinoma. Oncol Lett 2016;12:40614067.

46 Wei S, Fan Q, Yang L, Zhang X, Ma Y, Zong Z, Hua X, Su D, Sun H, Li H, Liu Z: Promotion of glycolysis by hotair through glut1 upregulation via mtor signaling. Oncol Rep 2017;38:1902-1908.

47 Bian EB, Wang YY, Yang Y, Wu BM, Xu T, Meng XM, Huang C, Zhang L, Lv XW, Xiong ZG, Li J: Hotair facilitates hepatic stellate cells activation and fibrogenesis in the liver. Biochim Biophys Acta 2017;1863:674-686.

48 Wu L, Zhang L, Zheng S: Role of the long non-coding rna hotair in hepatocellular carcinoma. Oncol Lett 2017;14:1233-1239.

49 Zhou JJ, Cheng D, He XY, Meng Z, Ye HL, Chen RF: Knockdown of long non-coding rna hotair sensitizes hepatocellular carcinoma cell to cisplatin by suppressing the stat3/abcb1 signaling pathway. Oncol Lett 2017;14:7986-7992.

-50 Li H, Tang XM, Liu Y, Li W, Chen Q, Pan Y: Association of functional genetic variants of hotair with hepatocellular carcinoma (hcc) susceptibility in a chinese population. Cell Physiol Biochem 2017;44:447454.

51 Siegel RL, Miller KD, Jemal A: Cancer statistics, 2016. CA Cancer J Clin 2016;66:7-30.

52 Smolle MA, Bullock MD, Ling H, Pichler M, Haybaeck J: Long non-coding rnas in endometrial carcinoma. Int J Mol Sci 2015;16:26463-26472.

53 Zhang A, Zhang J, Kaipainen A, Lucas JM, Yang H: Long non-coding rna: A newly deciphered "code" in prostate cancer. Cancer Lett 2016;375:323-330.

54 Li L, Dang Q Xie H, Yang Z, He D, Liang L, Song W, Yeh S, Chang C: Infiltrating mast cells enhance prostate cancer invasion via altering lncrna-hotair/prc2-androgen receptor (ar)-mmp9 signals and increased stem/ progenitor cell population. Oncotarget 2015;6:14179-14190.

55 Zhang A, Zhao JC, Kim J, Fong KW, Yang YA, Chakravarti D, Mo YY, Yu J: Lncrna hotair enhances the androgen-receptor-mediated transcriptional program and drives castration-resistant prostate cancer. Cell Rep 2015;13:209-221.

56 Ganai AA, Farooqi H: Bioactivity of genistein: A review of in vitro and in vivo studies. Biomed Pharmacother 2015;76:30-38.

-57 Chiyomaru T, Yamamura S, Fukuhara S, Yoshino H, Kinoshita T, Majid S, Saini S, Chang I, Tanaka Y, Enokida H, Seki N, Nakagawa M, Dahiya R: Genistein inhibits prostate cancer cell growth by targeting mir-34a and oncogenic hotair. PLoS One 2013;8:e70372.

58 Ling Z, Wang X, Tao T, Zhang L, Guan H, You Z, Lu K, Zhang G, Chen S, Wu J, Qian J, Liu H, Xu B, Chen M: Involvement of aberrantly activated hotair/ezh2/mir-193a feedback loop in progression of prostate cancer. J Exp Clin Cancer Res 2017;36:159.

-59 Xiang S, Zou P, Tang Q, Zheng F, Wu J, Chen Z, Hann SS: Hotair-mediated reciprocal regulation of ezh2 and dnmt1 contribute to polyphyllin i-inhibited growth of castration-resistant prostate cancer cells in vitro and in vivo. Biochim Biophys Acta 2017;1862:589-599.

60 Nagini S: Breast cancer: Current molecular therapeutic targets and new players. Anticancer Agents Med Chem 2017;17:152-163.

61 Sorensen KP, Thomassen M, Tan Q Bak M, Cold S, Burton M, Larsen MJ, Kruse TA: Long non-coding rna hotair is an independent prognostic marker of metastasis in estrogen receptor-positive primary breast cancer. Breast Cancer Res Treat 2013;142:529-536.

62 Yang H, Zhou J, Mi J, Ma K, Fan Y, Ning J, Wang C, Wei X, Zhao H, Li E: Hoxd10 acts as a tumor-suppressive factor via inhibition of the rhoc/akt/mapk pathway in human cholangiocellular carcinoma. Oncol Rep 2015;34:1681-1691.

63 Zhou Y, Wang C, Liu X, Wu C, Yin H: Long non-coding rna hotair enhances radioresistance in mda-mb231 breast cancer cells. Oncol Lett 2017;13:1143-1148.

64 Yu Y, Lv F, Liang D, Yang Q Zhang B, Lin H, Wang X, Qian G, Xu J, You W: Hotair may regulate proliferation, apoptosis, migration and invasion of mcf-7 cells through regulating the p53/akt/jnk signaling pathway. Biomed Pharmacother 2017;90:555-561. 


\section{Cellular Physiology Cell Physiol Biochem 2018;47:893-913 \begin{tabular}{l|l} 
DOI: 10.1159/000490131 & $\begin{array}{l}\text { O 2018 The Author(s). Published by S. Karger AG, Basel } \\
\text { www.karger.com/cpb }\end{array}$ \\
\hline
\end{tabular} \\ Tang/Hann: HOTAIR in Human Cancer}

-65 Zhou HY, Katsman Y, Dhaliwal NK, Davidson S, Macpherson NN, Sakthidevi M, Collura F, Mitchell JA: A sox2 distal enhancer cluster regulates embryonic stem cell differentiation potential. Genes Dev 2014;28:26992711.

-66 Deng J, Yang M, Jiang R, An N, Wang X, Liu B: Long non-coding rna hotair regulates the proliferation, selfrenewal capacity, tumor formation and migration of the cancer stem-like cell (csc) subpopulation enriched from breast cancer cells. PLoS One 2017;12:e0170860.

67 He H, Wei Z, Du F, Meng C, Zheng D, Lai Y, Yao H, Zhou H, Wang N, Luo XG, Ma W, Zhang TC: Transcription of hotair is regulated by rhoc-mrtf-a-srf signaling pathway in human breast cancer cells. Cell Signal 2017;31:87-95.

68 Katoh M, Igarashi M, Fukuda H, Nakagama H, Katoh M: Cancer genetics and genomics of human fox family genes. Cancer Lett 2013;328:198-206.

-69 Milevskiy MJ, Al-Ejeh F, Saunus JM, Northwood KS, Bailey PJ, Betts JA, McCart Reed AE, Nephew KP, Stone A, Gee JM, Dowhan DH, Dray E, Shewan AM, French JD, Edwards SL, Clark SJ, Lakhani SR, Brown MA: Longrange regulators of the lncrna hotair enhance its prognostic potential in breast cancer. Hum Mol Genet 2016;25:3269-3283.

70 Padua Alves C, Fonseca AS, Muys BR, de Barros ELBR, Burger MC, de Souza JE, Valente V, Zago MA, Silva WA, Jr.: Brief report: The lincrna hotair is required for epithelial-to-mesenchymal transition and stemness maintenance of cancer cell lines. Stem Cells 2013;31:2827-2832.

71 Ding W, Ren J, Ren H, Wang D: Long noncoding rna hotair modulates mir-206-mediated bcl-w signaling to facilitate cell proliferation in breast cancer. Sci Rep 2017;7:17261.

-72 Sun W, Yang Y, Xu C, Xie Y, Guo J: Roles of long noncoding rnas in gastric cancer and their clinical applications. J Cancer Res Clin Oncol 2016;142:2231-2237.

73 Sun M, Nie FQ Wang ZX, De W: Involvement of Incrna dysregulation in gastric cancer. Histol Histopathol 2016;31:33-39.

74 Wang J, Song YX, Wang ZN: Non-coding rnas in gastric cancer. Gene 2015;560:1-8.

75 Endo H, Shiroki T, Nakagawa T, Yokoyama M, Tamai K, Yamanami H, Fujiya T, Sato I, Yamaguchi K, Tanaka N, Iijima K, Shimosegawa T, Sugamura K, Satoh K: Enhanced expression of long non-coding rna hotair is associated with the development of gastric cancer. PLoS One 2013;8:e77070.

-76 Xu ZY, Yu QM, Du YA, Yang LT, Dong RZ, Huang L, Yu PF, Cheng XD: Knockdown of long non-coding rna hotair suppresses tumor invasion and reverses epithelial-mesenchymal transition in gastric cancer. Int J Biol Sci 2013;9:587-597.

77 Yan J, Dang Y, Liu S, Zhang Y, Zhang G: Lncrna hotair promotes cisplatin resistance in gastric cancer by targeting mir-126 to activate the pi3k/akt/mrp1 genes. Tumour Biol 2016

78 Ma T, Wang RP, Zou X: Dioscin inhibits gastric tumor growth through regulating the expression level of lncrna hotair. BMC Complement Altern Med 2016;16:383.

79 Song B, Guan Z, Liu F, Sun D, Wang K, Qu H: Long non-coding rna hotair promotes hla-g expression via inhibiting mir-152 in gastric cancer cells. Biochem Biophys Res Commun 2015;464:807-813.

-80 Liu YW, Sun M, Xia R, Zhang EB, Liu XH, Zhang ZH, Xu TP, De W, Liu BR, Wang ZX: Linchotair epigenetically silences mir34a by binding to prc2 to promote the epithelial-to-mesenchymal transition in human gastric cancer. Cell Death Dis 2015;6:e1802.

-81 Zhang J, Liu X, You LH, Zhou RZ: Significant association between long non-coding rna hotair polymorphisms and cancer susceptibility: A meta-analysis. Onco Targets Ther 2016;9:3335-3343.

82 Liu FT, Zhou L, Qiu C, Xia G, Zhu PQ, Luo HL: Association of the hotair rs4759314 polymorphism with cancer risk: A meta-analysis. J BUON 2016;21:1016-1023.

83 Du M, Wang W, Jin H, Wang Q, Ge Y, Lu J, Ma G, Chu H, Tong N, Zhu H, Wang M, Qiang F, Zhang Z: The association analysis of Incrna hotair genetic variants and gastric cancer risk in a chinese population. Oncotarget 2015;6:31255-31262.

84 Svoboda M, Slyskova J, Schneiderova M, Makovicky P, Bielik L, Levy M, Lipska L, Hemmelova B, Kala Z, Protivankova M, Vycital O, Liska V, Schwarzova L, Vodickova L, Vodicka P: Hotair long non-coding rna is a negative prognostic factor not only in primary tumors, but also in the blood of colorectal cancer patients. Carcinogenesis 2014;35:1510-1515.

-85 Wu ZH, Wang XL, Tang HM, Jiang T, Chen J, Lu S, Qiu GQ, Peng ZH, Yan DW: Long non-coding rna hotair is a powerful predictor of metastasis and poor prognosis and is associated with epithelial-mesenchymal transition in colon cancer. Oncol Rep 2014;32:395-402. 


\section{Cellular Physiology Cell Physiol Biochem 2018;47:893-913

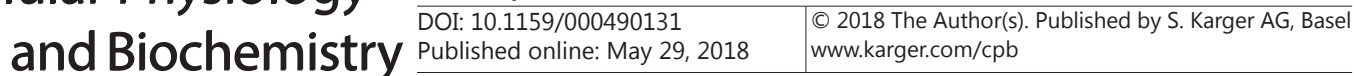 \\ Tang/Hann: HOTAIR in Human Cancer}

-86 Kogo R, Shimamura T, Mimori K, Kawahara K, Imoto S, Sudo T, Tanaka F, Shibata K, Suzuki A, Komune S, Miyano S, Mori M: Long noncoding rna hotair regulates polycomb-dependent chromatin modification and is associated with poor prognosis in colorectal cancers. Cancer Res 2011;71:6320-6326.

-87 Huang X, Lu S: Micror-545 mediates colorectal cancer cells proliferation through up-regulating epidermal growth factor receptor expression in hotair long non-coding rna dependent. Mol Cell Biochem 2017;431:45-54.

-88 Dou J, Ni Y, He X, Wu D, Li M, Wu S, Zhang R, Guo M, Zhao F: Decreasing lncrna hotair expression inhibits human colorectal cancer stem cells. Am J Transl Res 2016;8:98-108.

89 Yang XD, Xu HT, Xu XH, Ru G, Liu W, Zhu JJ, Wu YY, Zhao K, Wu Y, Xing CG, Zhang SY, Cao JP, Li M: Knockdown of long non-coding rna hotair inhibits proliferation and invasiveness and improves radiosensitivity in colorectal cancer. Oncol Rep 2016;35:479-487.

-90 Li P, Zhang X, Wang L, Du L, Yang Y, Liu T, Li C, Wang C: Lncrna hotair contributes to 5 fu resistance through suppressing mir-218 and activating nf-kappab/ts signaling in colorectal cancer. Mol Ther Nucleic Acids 2017;8:356-369.

91 Xue Y, Gu D, Ma G, Zhu L, Hua Q, Chu H, Tong N, Chen J, Zhang Z, Wang M: Genetic variants in Incrna hotair are associated with risk of colorectal cancer. Mutagenesis 2015;30:303-310.

92 Peng L, Yuan X, Jiang B, Tang Z, Li GC: Lncrnas: Key players and novel insights into cervical cancer. Tumour Biol 2016;37:2779-2788.

$\$ 93$ Jing L, Yuan W, Ruofan D, Jinjin Y, Haifeng Q: Hotair enhanced aggressive biological behaviors and induced radio-resistance via inhibiting p21 in cervical cancer. Tumour Biol 2015;36:3611-3619.

$\$ 94$ Li J, Wang Y, Yu J, Dong R, Qiu H: A high level of circulating hotair is associated with progression and poor prognosis of cervical cancer. Tumour Biol 2015;36:1661-1665.

95 Lee M, Kim HJ, Kim SW, Park SA, Chun KH, Cho NH, Song YS, Kim YT: The long non-coding rna hotair increases tumour growth and invasion in cervical cancer by targeting the notch pathway. Oncotarget 2016;7:44558-44571.

-96 Sun J, Chu H, Ji J, Huo G, Song Q Zhang X: Long non-coding rna hotair modulates hla-g expression by absorbing mir-148a in human cervical cancer. Int J Oncol 2016;49:943-952.

$\$ 97$ Ji F, Wuerkenbieke D, He Y, Ding Y: Long noncoding rna hotair: An oncogene in human cervical cancer interacting with microrna-17-5p. Oncol Res 2017

-98 Zhang D, Zhou XH, Zhang J, Zhou YX, Ying J, Wu GQ Qian JH: Propofol promotes cell apoptosis via inhibiting hotair mediated mtor pathway in cervical cancer. Biochem Biophys Res Commun 2015;468:561-567.

-99 Guo L, Lu X, Zheng L, Liu X, Hu M: Association of long non-coding rna hotair polymorphisms with cervical cancer risk in a chinese population. PLoS One 2016;11:e0160039.

100 Jin H, Lu X, Ni J, Sun J, Gu B, Ding B, Zhu H, Ma C, Cui M, Xu Y, Zhang Z, Lercher M, Chen J, Gao N, Wang S: Hotair rs7958904 polymorphism is associated with increased cervical cancer risk in a chinese population. Sci Rep 2017;7:3144.

101 Sharma Saha S, Roy Chowdhury R, Mondal NR, Chakravarty B, Chatterjee T, Roy S, Sengupta S: Identification of genetic variation in the Incrna hotair associated with hpv16-related cervical cancer pathogenesis. Cell Oncol (Dordr) 2016;39:559-572.

102 Qiu JJ, Lin YY, Ye LC, Ding JX, Feng WW, Jin HY, Zhang Y, Li Q Hua KQ: Overexpression of long non-coding rna hotair predicts poor patient prognosis and promotes tumor metastasis in epithelial ovarian cancer. Gynecol Oncol 2014;134:121-128.

103 Teschendorff AE, Lee SH, Jones A, Fiegl H, Kalwa M, Wagner W, Chindera K, Evans I, Dubeau L, Orjalo A, Horlings HM, Niederreiter L, Kaser A, Yang W, Goode EL, Fridley BL, Jenner RG, Berns EM, Wik E, Salvesen HB, Wisman GB, van der Zee AG, Davidson B, Trope CG, Lambrechts S, Vergote I, Calvert H, Jacobs IJ, Widschwendter M: Hotair and its surrogate DNA methylation signature indicate carboplatin resistance in ovarian cancer. Genome Med 2015;7:108.

104 Wang Y, Wang H, Song T, Zou Y, Jiang J, Fang L, Li P: Hotair is a potential target for the treatment of cisplatinresistant ovarian cancer. Mol Med Rep 2015;12:2211-2216.

105 Qiu JJ, Wang Y, Ding JX, Jin HY, Yang G, Hua KQ: The long non-coding rna hotair promotes the proliferation of serous ovarian cancer cells through the regulation of cell cycle arrest and apoptosis. Exp Cell Res 2015;333:238-248.

106 Luo P, Liu XF, Wang YC, Li ND, Liao SJ, Yu MX, Liang CZ, Tu JC: Prognostic value of abnormally expressed lncrnas in ovarian carcinoma: A systematic review and meta-analysis. Oncotarget 2017;8:23927-23936. 


\section{Cellular Physiology Cell Physiol Biochem 2018;47:893-913

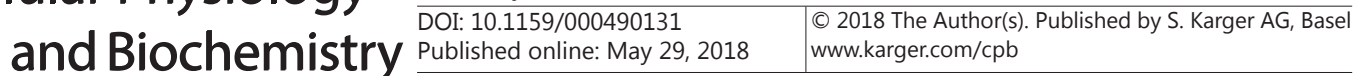 \\ Tang/Hann: HOTAIR in Human Cancer}

107 Ozes AR, Miller DF, Ozes ON, Fang F, Liu Y, Matei D, Huang T, Nephew KP: Nf-kappab-hotair axis links DNA damage response, chemoresistance and cellular senescence in ovarian cancer. Oncogene 2016;35:53505361.

108 Yiwei T, Hua H, Hui G, Mao M, Xiang L: Hotair interacting with mapk1 regulates ovarian cancer skov3 cell proliferation, migration, and invasion. Med Sci Monit 2015;21:1856-1863.

109 Li J, Yang S, Su N, Wang Y, Yu J, Qiu H, He X: Overexpression of long non-coding rna hotair leads to chemoresistance by activating the wnt/beta-catenin pathway in human ovarian cancer. Tumour Biol 2016;37:2057-2065.

110 Ozes AR, Wang Y, Zong X, Fang F, Pilrose J, Nephew KP: Therapeutic targeting using tumor specific peptides inhibits long non-coding rna hotair activity in ovarian and breast cancer. Sci Rep 2017;7:894.

111 Huang J, Ke P, Guo L, Wang W, Tan H, Liang Y, Yao S: Lentivirus-mediated rna interference targeting the long noncoding rna hotair inhibits proliferation and invasion of endometrial carcinoma cells in vitro and in vivo. Int J Gynecol Cancer 2014;24:635-642.

112 He X, Bao W, Li X, Chen Z, Che Q Wang H, Wan XP: The long non-coding rna hotair is upregulated in endometrial carcinoma and correlates with poor prognosis. Int J Mol Med 2014;33:325-332.

113 Sun MY, Zhu JY, Zhang CY, Zhang M, Song YN, Rahman K, Zhang LJ, Zhang H: Autophagy regulated by lncrna hotair contributes to the cisplatin-induced resistance in endometrial cancer cells. Biotechnol Lett 2017

114 Kang H KA, Chung CH: Emerging biomarkers in head and neck cancer in the era of genomics. Nat Rev Clin Oncol 2015;12:11-26.

115 Kong L, Zhou X, Wu Y, Wang Y, Chen L, Li P, Liu S, Sun S, Ren Y, Mei M, Wang X, Zhang L: Targeting hotair induces mitochondria related apoptosis and inhibits tumor growth in head and neck squamous cell carcinoma in vitro and in vivo. Curr Mol Med 2015;15:952-960.

116 Kotta-Loizou I, Giaginis C, Theocharis S: Clinical significance of hur expression in human malignancy. Med Oncol 2014;31:161.

117 Xu CZ, Jiang C, Wu Q Liu L, Yan X, Shi R: A feed-forward regulatory loop between hur and the long noncoding rna hotair promotes head and neck squamous cell carcinoma progression and metastasis. Cell Physiol Biochem 2016;40:1039-1051.

$118 \mathrm{Wu}$ J, Xie H: Expression of long noncoding rna-hox transcript antisense intergenic rna in oral squamous cell carcinoma and effect on cell growth. Tumour Biol 2015;36:8573-8578.

119 Wu Y, Zhang L, Zhang L, Wang Y, Li H, Ren X, Wei F, Yu W, Liu T, Wang X, Zhou X, Yu J, Hao X: Long noncoding rna hotair promotes tumor cell invasion and metastasis by recruiting ezh2 and repressing e-cadherin in oral squamous cell carcinoma. Int J Oncol 2015;46:2586-2594.

120 Lu MY, Liao YW, Chen PY, Hsieh PL, Fang CY, Wu CY, Yen ML, Peng BY, Wang DP, Cheng HC, Wu CZ, Shih YH, Wang DJ, Yu CC, Tsai LL: Targeting Incrna hotair suppresses cancer stemness and metastasis in oral carcinomas stem cells through modulation of emt. Oncotarget 2017;8:98542-98552.

121 Fu WM LY, Hu BG, Liang WC, Zhu X, Yang HD, Li G, Zhang JF.: Long noncoding rna hotair mediated angiogenesis in nasopharyngeal carcinoma by direct and indirect signaling pathways. Oncotarget 2016 7:4712-4723.

122 Nie Y, Liu X, Qu S, Song E, Zou H, Gong C: Long non-coding rna hotair is an independent prognostic marker for nasopharyngeal carcinoma progression and survival. Cancer Sci 2013;104:458-464.

123 Ma DD, Yuan LL, Lin LQ: Lncrna hotair contributes to the tumorigenesis of nasopharyngeal carcinoma via up-regulating fasn. Eur Rev Med Pharmacol Sci 2017;21:5143-5152.

124 Wang J, Zhou Y, Lu J, Sun Y, Xiao H, Liu M, Tian L: Combined detection of serum exosomal mir-21 and hotair as diagnostic and prognostic biomarkers for laryngeal squamous cell carcinoma. Med Oncol 2014;31:148.

125 Li D, Feng J, Wu T, Wang Y, Sun Y, Ren J, Liu M: Long intergenic noncoding rna hotair is overexpressed and regulates pten methylation in laryngeal squamous cell carcinoma. Am J Pathol 2013;182:64-70.

126 Zheng J, Xiao X, Wu C, Huang J, Zhang Y, Xie M, Zhang M, Zhou L: The role of long non-coding rna hotair in the progression and development of laryngeal squamous cell carcinoma interacting with ezh2. Acta Otolaryngol 2017; 137:90-98.

127 Ge XS, Ma HJ, Zheng XH, Ruan HL, Liao XY, Xue WQ, Chen YB, Zhang Y, Jia WH: Hotair, a prognostic factor in esophageal squamous cell carcinoma, inhibits wif-1 expression and activates wnt pathway. Cancer Sci 2013;104:1675-1682.

128 Song W, Zou SB: Prognostic role of Incrna hotair in esophageal squamous cell carcinoma. Clin Chim Acta 2016;463:169-173. 


\section{Cellular Physiology Cell Physiol Biochem 2018;47:893-913 \begin{tabular}{ll|l} 
and Biochemistry & $\begin{array}{l}\text { DOI: 10.1159/000490131 } \\
\text { Published online: May 29, } 2018\end{array}$ & $\begin{array}{l}\text { @ 2018 The Author(s). Published by S. Karger AG, Basel } \\
\text { www.karger.com/cpb }\end{array}$ \\
\hline
\end{tabular} \\ Tang/Hann: HOTAIR in Human Cancer}

129 Chen FJ, Sun M, Li SQ Wu QQ, Ji L, Liu ZL, Zhou GZ, Cao G, Jin L, Xie HW, Wang CM, Lv J, De W, Wu M, Cao XF: Upregulation of the long non-coding rna hotair promotes esophageal squamous cell carcinoma metastasis and poor prognosis. Mol Carcinog 2013;52:908-915.

130 Wang W, He X, Zheng Z, Ma X, Hu X, Wu D, Wang M: Serum hotair as a novel diagnostic biomarker for esophageal squamous cell carcinoma. Mol Cancer 2017;16:75.

131 Li X, Wu Z, Mei Q Li X, Guo M, Fu X, Han W: Long non-coding rna hotair, a driver of malignancy, predicts negative prognosis and exhibits oncogenic activity in oesophageal squamous cell carcinoma. Br J Cancer 2013;109:2266-2278.

132 Xu Y, Qiu M, Chen Y, Wang J, Xia W, Mao Q, Yang L, Li M, Jiang F, Xu L, Yin R: Long noncoding rna, tissue differentiation-inducing nonprotein coding rna is upregulated and promotes development of esophageal squamous cell carcinoma. Dis Esophagus 2016;29:950-958.

133 Da C, Zhan Y, Li Y, Tan Y, Li R, Wang R: The expression and significance of hox transcript antisense rna and epithelial-mesenchymal transition-related factors in esophageal squamous cell carcinoma. Mol Med Rep 2017;15:1853-1862.

134 Zhang X, Zhou L, Fu G, Sun F, Shi J, Wei J, Lu C, Zhou C, Yuan Q Yang M: The identification of an escc susceptibility snp rs 920778 that regulates the expression of lncrna hotair via a novel intronic enhancer. Carcinogenesis 2014;35:2062-2067.

135 Zhu H, Lv Z, An C, Shi M, Pan W, Zhou L, Yang W, Yang M: Onco-lncrna hotair and its functional genetic variants in papillary thyroid carcinoma. Sci Rep 2016;6:31969.

136 Garitano-Trojaola A, Agirre X, Prosper F, Fortes P: Long non-coding rnas in haematological malignancies. Int J Mol Sci 2013;14:15386-15422.

137 Isin M, Ozgur E, Cetin G, Erten N, Aktan M, Gezer U, Dalay N: Investigation of circulating lncrnas in b-cell neoplasms. Clin Chim Acta 2014;431:255-259.

138 Zhang YY, Huang SH, Zhou HR, Chen CJ, Tian LH, Shen JZ: Role of hotair in the diagnosis and prognosis of acute leukemia. Oncol Rep 2016;36:3113-3122.

139 Hao S, Shao Z: Hotair is upregulated in acute myeloid leukemia and that indicates a poor prognosis. Int J Clin Exp Pathol 2015;8:7223-7228.

140 Wu S, Zheng C, Chen S, Cai X, Shi Y, Lin B, Chen Y: Overexpression of long non-coding rna hotair predicts a poor prognosis in patients with acute myeloid leukemia. Oncol Lett 2015;10:2410-2414.

-141 Xing CY, Hu XQ, Xie FY, Yu ZJ, Li HY, Bin Z, Wu JB, Tang LY, Gao SM: Long non-coding rna hotair modulates c-kit expression through sponging mir-193a in acute myeloid leukemia. FEBS Lett 2015;589:1981-1987.

142 Sayad A, Hajifathali A, Hamidieh AA, Roshandel E, Taheri M: Hotair long noncoding rna is not a biomarker for acute myeloid leukemia (aml) in iranian patients. Asian Pac J Cancer Prev 2017;18:1581-1584.

143 Zhang X, Weissman SM, Newburger PE: Long intergenic non-coding rna hotairm1 regulates cell cycle progression during myeloid maturation in nb4 human promyelocytic leukemia cells. RNA Biol 2014;11:777-787.

144 Yan Y, Han J, Li Z, Yang H, Sui Y, Wang M: Elevated rna expression of long noncoding hotair promotes cell proliferation and predicts a poor prognosis in patients with diffuse large b cell lymphoma. Mol Med Rep 2016;13:5125-5131.

145 Miura M: Therapeutic drug monitoring of imatinib, nilotinib, and dasatinib for patients with chronic myeloid leukemia. Biol Pharm Bull 2015;38:645-654.

146 Wang H, Li Q, Tang S, Li M, Feng A, Qin L, Liu Z, Wang X: The role of long noncoding rna hotair in the acquired multidrug resistance to imatinib in chronic myeloid leukemia cells. Hematology 2017;22:208216.

147 Ma MZ, Li CX, Zhang Y, Weng MZ, Zhang MD, Qin YY, Gong W, Quan ZW: Long non-coding rna hotair, a c-myc activated driver of malignancy, negatively regulates mirna-130a in gallbladder cancer. Mol Cancer 2014;13:156.

148 Zhang K, Sun X, Zhou X, Han L, Chen L, Shi Z, Zhang A, Ye M, Wang Q, Liu C, Wei J, Ren Y, Yang J, Zhang J, $\mathrm{Pu}$ P, Li M, Kang C: Long non-coding rna hotair promotes glioblastoma cell cycle progression in an ezh2 dependent manner. Oncotarget 2015;6:537-546.

149 Wang B, Su Y, Yang Q, Lv D, Zhang W, Tang K, Wang H, Zhang R, Liu Y: Overexpression of long non-coding rna hotair promotes tumor growth and metastasis in human osteosarcoma. Mol Cells 2015;38:432-440.

150 Zheng H, Min J: Role of long noncoding rna hotair in the growth and apoptosis of osteosarcoma cell mg-63. Biomed Res Int 2016;2016:5757641.

151 Wu Y, Liu J, Zheng Y, You L, Kuang D, Liu T: Suppressed expression of long non-coding rna hotair inhibits proliferation and tumourigenicity of renal carcinoma cells. Tumour Biol 2014;35:11887-11894. 